\title{
Affective Robotics: Modelling and Testing Cultural Prototypes
}

\author{
Paul A. Wilson · Barbara Lewandowska-Tomaszczyk
}

Received: 15 December 2013/Accepted: 21 July 2014/Published online: 14 August 2014

(C) The Author(s) 2014. This article is published with open access at Springerlink.com

\begin{abstract}
If robots are to successfully interact with humans, they need to measure, quantify and respond to the emotions we produce. Similar to humans, the perceptual cue inputs to any modelling that allows this will be based on behavioural expression and body activity features that are prototypical of each emotion. However, the likely employment of such robots in different cultures necessitates the tuning of the emotion feature recognition system to the specific feature profiles present in these cultures. The amount of tuning depends on the relative convergence of the cross-cultural mappings between the emotion feature profiles of the cultures where the robots will be used. The GRID instrument and the cognitive corpus linguistics methodology were used in a contrastive study analysing a selection of behavioural expression and body activity features to compare the feature profiles of joy, sadness, fear and anger within and between Polish and British English. The intra-linguistic differences that were found in the profile of emotion features suggest that weightings based on this profile can be used in robotic modelling to create emotion-sensitive socially interacting robots. Our crosscultural results further indicate that this profile of features needs to be tuned in robots to make them emotionally competent in different cultures.
\end{abstract}

Keywords Affective robotics - Body features of emotion - Corpus materials - Culture prototypes . Emotion event scenario · GRID

P. A. Wilson $(\bowtie) \cdot$ B. Lewandowska-Tomaszczyk

University of Lodz, Lodz, Poland

e-mail: p.wilson@psychology.bbk.ac.uk

\section{Introduction}

To accomplish successful social interaction with humans, robots need to identify and respond to emotions. In order to achieve human-like competence in decoding emotions, such robots would need to measure and quantify the same sensory cues that are processed by humans, namely linguistic, paralinguistic, facial, body movement and physiological features. One of the aims of the present study reported in this paper was to compare sadness, joy, fear and anger on such sensory cues within British English and within Polish. Generally recognised as basic emotions, joy, sadness, fear and anger were selected on the basis of being relatively common emotions that signify the occurrence of important events. It is such central emotions that emotion-sensitive socially interacting robots should be able to detect and respond to if they are to be emotionally competent socially interacting beings. Although there has been progress in research investigating robotic recognition and interpretation of sensory cues with regard to emotion identification, relatively little empirical attention has been focused on how socially interactive robots might overcome cross-cultural challenges in order to accurately decode emotions in different cultures. The second and main aim of our study was to investigate such challenges by assessing the differences between Polish and British English in the profiles of joy, sadness, fear and anger on linguistic, paralinguistic, facial, body movement and physiological features. Any socially interactive entity, be it a human or a robot, would need to distinguish between these differences to successfully decode emotions in the two cultures.

The wealth of recent studies showing cross-linguistic and cross-cultural differences in emotions highlights the 
challenge that emotion-sensitive interactive robots face if they are to interact socially in different languages and cultures. In our research employing the GRID (see below for more details) and corpus methodologies, we have observed, for example, that British English fear is more of an energising emotion than its Polish counterpart strach, suggesting that British English fear is more akin to a variant of fear in which an individual feels powerful and dominant and, if successful, is in control of fear [18]. We have also shown that Polish and English differ in their emotional profiles of happiness and contentment [37], and surprise [17]. Other studies have shown similar inequivalences in language terms across languages and cultures. For example, Alonso-Arbiol and van der Vijer [1] observed that whereas Spanish 'desesperación' (despair) is a combination of sadness and the anger elements of frustration/ exasperation, the English and Basque ('etsipena') equivalents are instances of a more general sadness category. Demonstrating cross-cultural emotion differences within one language, Mortillaro et al. [20] show that whereas Southern Italians conceptualise pride negatively, Northern Italians consider pride to be a comparably more positive emotion. The results of a study by Ishii [12] revealed that whereas happiness was associated more with pride in American English on bodily reaction features, it was more connected with love on these features in Japanese. The question that arises is whether such diverse cross-linguistic and cross-cultural differences have a theoretical explanation. Although some of the inequivalent cross-linguistic and cross-cultural emotion patterning is accounted for within the framework of Hofstede's [11] collectivism versus individualism, other findings appear idiosyncratic to specific cultures and fall outside overarching theoretical explanation. The main aim of the present study was to assess the differences between Polish and British English in the expression feature profiles of joy, sadness, fear and anger that might be decoded by a socially competent robot, as it is these differences that any entity navigating within a socially interactive environment would need to identify in order to operate successfully at an emotional level. Therefore, the approach adopted in the present paper is pragmatic in the sense of identifying differences in emotion features that would allow robots to be linguistically and culturally competent in terms of emotion differences rather than identifying the underlying theoretical reasons for these differences. ${ }^{1}$

Our contribution to affective robotics in the present paper presupposes a theory of human emotions and

\footnotetext{
1 Although we view the identification of the underlying reasons for cross-linguistic and cross-cultural differences in emotions as an important academic endeavour, it is beyond the scope and focus of the present paper.
}

includes their description and presentation. Social robotics considers emotions in their broad biological sense as automated homoeostatic regulation [5] at different levels of biological behaviour, including man-robot linguistic communication. Taken in this sense, robots, both expressing artificial emotions as well as perceiving and recognising them, can be modelled in terms of emotionalhomoeostatic architecture. The research methodology applied can either be more directly applicable at the interface and robot design of emotion modelling or can provide some materials on which to further develop models of socially interactive robots to be used in different functions such as medical and therapeutic aids and educational and entertaining devices.

While preliminary emphasis in social robotics is conventionally put on dyadic query-response acts in manmachine communication, more sophisticated modelling will involve more varied signals (components) and patterns of linguistic structures and behaviour for emotion recognition and expression. A change of events in the surrounding is often signalled via (bodily and linguistic) emotional behaviour in human agents and is likely to be perceived as such by robots. In other words, human emotional behaviour, expressed by our bodies and language, signals changes in the contextual surrounding, and whereas some of these can be, for instance, threatening and induce fear, others will be entertaining and constitute antecedents of joy.

Our emotion research uses two approaches to emotion studies: the GRID and cognitive corpus linguistics methodologies. The GRID instrument [9, 26] employs a system of dimensions and components, which bring about insight into the nature of emotion prototypical structures. The GRID project is coordinated by the Swiss Center for Affective Sciences at the University of Geneva in collaboration with Ghent University and is a worldwide study of emotional patterning across 23 languages and 27 countries. The GRID instrument comprises a Web-based questionnaire in which 24 prototypical emotion terms are evaluated on 144 emotion features. These features represent activity in all six of the major components of emotion. Thirty-one features relate to appraisals of events, eighteen to psychophysiological changes, twenty-six to facial, vocal or gestural expressions, forty to action tendencies, twentytwo to subjective experiences and four to emotion regulation. An additional three features refer to other qualities, such as frequency and social acceptability of the emotion. Participants are asked to rate the likelihood of these features for the various emotions. This methodology is comprehensive in its scope as it allows the multicultural comparison of emotion conceptualisations on all six of the emotion categories recognised by emotion theorists [7, 21, 26]. 
The cognitive corpus linguistics approach provides information on the probabilities of the occurrence of some linguistic patterns of emotional language use based on their frequencies and distributional patterns. Both methods are employed in the context of basic emotion event scenarios (EES) (Lewandowska-Tomaszczyk and Wilson [19], which identify the effects of emotion stimuli on Experiencer, and his/her embodied (bodily and mental) and exbodied reactions, linguistically expressed via segmental and prosodic properties, which characterise some but not other emotional states. Our proposal of a Prototypical EES [36] covers the following constituents:

Context (Biological predispositions of Experiencer; Social and Cultural conditioning; On-line contextual properties of Event) [Stimulus $\rightarrow$ Experiencer \{(internally and externally manifested) physiological and physical symptoms; affective state + (internally experienced) Emotion $\} \rightarrow$ possible external reaction(s) of Experiencer (blending; language: metaphor; emotion and emotional talk; non-verbal reactions)]

Language corpora are large collections of language materials, both spoken and written, and are representative of different linguistic styles and genres. The corpus materials used in the analysis reported in the present paper are derived from the British National Corpus (BNC: http:// www.natcorp.ox.ac.uk/ comprising 100 million words) and the National Corpus of Polish (nkjp.pl, comprising over 260 million words).

The internal structure of emotion concepts and the regularities in their co-occurrence with bodily and contextual emotion signals are also analysed, taking insight from cognitive linguistics [14], Langacker [15], particularly from the analysis of figurative (first of all, metaphoric) language. Metaphorisation is a mental process of perceiving one (usually more abstract) object or event in terms of another, which is typically a more concrete one.

Other relevant concepts in linguistics are collocations. A collocation [10] is a sequence of words or terms that cooccur more often than would be expected by chance. For example, the Polish phrase wpaść $w$ gniew (lit. 'fall in anger') is a conventional (metaphoric) collocation in Polish while in English the expression? fall in anger would not be considered correct by native speakers of English; by contrast, the expression fall in love would be fully acceptable as an English collocation. The 'fall in' metaphors in these collocations highlight the fairly sudden, frequently unexpected and not fully controlled, nature of this manifestation of emotion. Another metaphoric collocation involving the descriptive element of venting (e.g. he vented his embarrassment/anger/frustration by...) underlies the negative character of these emotions and the process which leads to decreased power and weakening of the Experiencer, letting metaphorical air (anger) escape or release from confinement and, similarly to a tyre, making it flat (devoid of tension-power). Metaphors and the verbal material in collocations are retrievable from corpus materials. Research on corpus data uncovers elements of the EES and is likely to point to the consequences of relevant stimuli, and the properties of major significance in emotionally threatening contexts and their possible negative outcomes, which are crucial for social robotics.

The tools used to generate concordance and collocation sets for both languages are a set of HASK tools (PelcraHask.pl), which display collocations in basic Part-OfSpeech patterns and their frequencies. ${ }^{2}$ Parts of speech are linguistic categories of words, which are characterised by similar (syntactic and morphological) properties and distribution in the sentence. The main parts of speech are Nouns (boy, chair, water, etc.), Adjectives (tall, old, lovely, etc.), Verbs (dance, write, grow, be, etc.) and Adverbs (slowly, well, fast, etc.).

Collocations with major parts of speech can be automatically generated from corpus data. Collocates of a word are generated in a window of 5 words before and after the investigated term, which is the standard practice in corpus linguistics, and the relevant $t$ test scores are provided. Programs calculate the degree of association between terms based on measures of association, which, in our study, refers to the value of Mutual Information (MI). Our software also offers the possibility of filtering the collocations in terms of their grammatical class (Nouns, Verbs, Adjectives), which we find useful to identify in order to elaborate on the components of particular Emotion Scenarios (Experiencers, Stimuli/Sources, etc.). The top 15 collocations for each of the Polish and English emotions relevant to the present paper are presented in the tables in the appendices. Regular patterns of collocation structure, in which an emotion term is a headword that co-occurs with its closest collocates, uncover regularities in Polish and English emotion content and corresponding behavioural correlates.

Secondly, in addition to inspecting a list of lexical collocates of an emotion word (e.g. fear, joy or sadness), there is an added value in looking at the full verbal contexts in which the word is used because it can reveal additional characteristics of the emotion (for example, eliciting event sources and its expression). The analysis of the phrases and sentences in which a word appears can be done through Key Word in Context (KWIC) searches, where the analyst specifies the word to be looked up, and the program

\footnotetext{
2 An Application Programming Interface for the English version of the HASK dictionary of frequent word combinations was automatically generated from the British National Corpus [24].
} 
retrieves all instances of use of that word in the corpus and its immediate context. The lexical items immediately surrounding a headword are also referred to as the word's concordance. In our methodology, additional properties of emotions generated from the corpora enrich and provide independent evidence for the characteristics obtained by means of the GRID questionnaire.

As observed in our previous studies [37], some emotions like happiness and szczeście, in some of their senses, display a more overlapping equivalent structure between English and Polish; however, some others (fear-strach and sadness-smutek) diverge to a larger extent. Additionally, there are emotions such as anger in English, which are conventionally correlated with two distinct counterparts in Polish, gniew and złość (see [33]; relevant lexicographic data is also available from bilingual dictionaries, e.g. Great English-Polish Dictionary 2002). In the present paper, we make an attempt to establish to what extent English anger is a blended combination of gniew and ztość, and in which contexts its behaviour in language use can provide clues to identify its two senses: one more similar to gniew -in which 'anger' designates a more predictable and controllable emotion and the other resembling złość-an emotion more difficult to constrain.

Our system does not provide all the information to enable explicit, rich-context modelling of emotion production or perception, but provides sufficient data to model culture-bound human-like emotional behaviour by resorting to the clusters of preferential conditions present in the implementation of a particular EES (see above) in a given cultural and linguistic context. In this sense, our data should be viewed as complementing other studies focusing on the robotic encoding and decoding of emotions.

In this study, we focus on the expression characteristics of emotions. More specifically, we look at five types of perceptual features (or 'sensory cues') that signal the presence of an emotion: linguistic features (e.g. produced a short utterance), paralinguistic features (e.g. had a trembling voice), facial features (e.g. frowned), body movement features (e.g. abrupt bodily movements) and physiological features (e.g. breathing getting faster). Accurate decoding of such sensory cues is fundamental to the interactive success that social robots need to achieve when communicating with humans. The data from the five categories of sensory cues reported in the present study are relevant to the main fields of robotics emotion research. Wimmer et al. [38] report that, in a model with facial feature extraction comprising structural and facial features, robots are able to recognise $67 \%$ of human facial expressions. Vogt et al. [30] outline solutions to the problems that prevent automatic emotion recognition systems being able to recognise human emotions from vocal cues in real time.
Castellano et al. [4] demonstrate that 'high' and 'low arousal' emotions can be distinguished from 'positive' and 'negative' emotions from expressive motion cues that could be used by artificial, automatic systems to decode emotions from human movement. Barber et al. [2] assess the state of the art regarding the robotic remote encoding of human physiological measures in natural settings and the steps that are necessary for humans to use this information in decision making. The common fundamental element of these studies is the identification of the sensory cues that socially interactive robots need to accurately decode if they are to successfully distinguish between human emotions.

We aim to investigate sensory cue profiles in the present study to determine both intra-linguistic and interlinguistic differences in emotion expression. Profiles of sensory cues have been employed effectively to determine conceptual differences between emotions within languages. For example, using the GRID methodology, Ogarkova et al. [22] analysed the means of sensory cue features (e.g. showed tears, spoke slower, frowned, spoke faster and felt hot) to show that Russian toska is conceptually closer to sadness than to anxiety/fear. Turning to a cross-linguistic perspective, Scherer and Walbott [27] employed a methodology in which participants from 37 countries were asked to provide physiological symptoms and expressive reactions, including bodily symptoms, non-verbal expressive reactions, and verbal reactions, to recalled, personal emotional situations. The relatively strong universal, emotion-specific effects showed differences in the profiles for joy, fear, anger, sadness, disgust, shame and guilt. It was observed, for example, that joy is characterised by very expressive non-verbal and verbal behaviour, a strong orientation towards other people and a feeling of warmth or heat. By contrast, sadness has a strong non-verbal expression but little vocal or verbal behaviour and is further characterised by an orientation away from other people and a feeling of being cold. Fear has a relatively lower outward expression, with high arousal and a feeling of coldness. Anger is characterised by high verbal and nonverbal expression, with high arousal and high felt temperature. These emotions were relatively consistent across the cultures examined, with only small to moderate interactions between country and emotion. However, it must be noted that the variables comprised the composite sum of sensory cue features. For example, the verbal behaviour variable was the sum of silence, short utterance, one/two sentences and long utterance. In comparison, more recent studies that have included a more fine-grained focus on specific sensory features in different perceptual modalities have shown more pronounced cross-cultural differences. Comparing Western 
Caucasian and East Asian observations of computermodelled facial expressions of happiness, surprise, fear, disgust, anger and sadness, Jack et al. [13] concluded that "facial expressions of emotion are culture specific" (p. 7242). Laukka et al. [16] employed machine learning simulations to classify the vocal expression of emotions produced by professional actors in 5 English-speaking cultures. Although there was some cross-cultural consistency in the classifications of emotions, further results showed a within-culture recognition advantage of vocally expressed emotions in comparison with the cross-cultural condition. To conclude, the emotion-specific effects regarding the differences in sensory cues appear to be greater than the cross-cultural differences. However, there is evidence, especially in more recent studies, pointing to more pronounced differences in such cues across cultures.

\section{GRID Methodology}

\section{Procedure}

Participants completed the GRID instrument in a controlled Web study [25], in which each participant was presented with four emotion terms randomly chosen from the set of 24 and asked to rate each in terms of the 144 emotion features. They rated the likelihood that each of the 144 emotion features can be inferred when a person from their cultural group uses the emotion term to describe an emotional experience. A 9-point scale was employed that ranged from extremely unlikely (1) to extremely likely (9)-the numbers 2 to 8 were placed at equidistant intervals between the two ends of the scale, with 5 'neither unlikely, nor likely' in the middle and participants typed their ratings on the keyboard. It was clearly stated that the participants needed to rate the likelihood of occurrence of each of the features when somebody who speaks their language describes an emotional experience with the emotion terms presented. Each of the 144 emotion features was presented separately, and participants rated all four emotion terms for that feature before proceeding to the next feature.

\section{Participants}

The mean ages and gender ratios of the participants for each of the emotion terms were as follows: joy (35 British English-speaking participants; mean age 21.3 years, 21 females); sadness (33 British English-speaking participants; mean age 21.7 years, 19 females); fear (36 British English-speaking participants; mean age 21.5 years, 21 females); and anger (32 British English-speaking participants; mean age 20.8 years, 20 females). The mean ages and gender ratios of the participants for each of the emotion terms were as follows: radość (27 Polish-speaking participants; mean age 22.3 years, 16 females); smutek (22 Polish-speaking participants; mean age 23.6 years, 14 females); strach (32 Polish-speaking participants; mean age 23.4 years, 19 females); złość (25 Polish-speaking participants; mean age 22.5 years, 13 females); and gniew (31 Polish-speaking participants; mean age 27.2 years, 18 females).

\section{GRID Features and Emotions}

The present study reported in this paper used thirty-three GRID features that were selected on the basis of behavioural expression or body activity and, apart from sing and dance, can be grouped into the following five categories: physiological features, facial expression features, body movement features, paralinguistic features and linguistic features (see Tables 1 and 2 for the selection of GRID features).

The emotions selected for the present study were British English sadness, joy, fear and anger, and their Polish counterparts smutek, radość, strach, złość and gniew, the latter two being common types of anger in Polish [33]. Anger was specifically chosen to highlight the complexity of cross-cultural differences that emotion-sensitive robots will need to address if they are to be used in different cultures.

Both intra-linguistic and English-Polish inter-linguistic differences are made more explicit in terms of the GRID components and in the corpus data as will be discussed in the sections to follow.

\section{GRID Dimensions}

In an initial study of the dimensional structure of emotions using the GRID instrument, Fontaine et al. [8] derived a four-dimensional structure for English, French and Dutch that comprised valence, power, arousal and novelty. Analyses performed on the data from all of the languages represented in the GRID project have reproduced this dimensional structure [9]. To determine the dimensional structure of the Polish and British English data in the present study, principle components analysis (PCA) with varimax rotation was performed on the combined dataset of these two languages. There were 201 British English participants (124 females) with a men age of 21.5 years, and 124 Polish participants (95 females) with a mean age of 23.2 years. The four-dimensional solution that was selected comprised the same dimensions as Fontaine et al. [8] and Fontaine et al. [9] and accounted for $81.9 \%$ of the total variance. The first dimension (valence) accounted for 
Table 1 Means and statistics for Sadness, Joy, Fear and Anger on selected behavioural expression and body activity GRID features
Significant differences between the means are denoted by the first letters of the emotions: ${ }^{\mathrm{S}}$ sadness, ${ }^{\mathrm{J}}$ joy, ${ }^{\mathrm{F}}$ fear and A anger

\begin{tabular}{|c|c|c|c|c|c|}
\hline \multirow[t]{2}{*}{ Feature } & \multicolumn{5}{|l|}{ Means } \\
\hline & Sadness & Joy & Fear & Anger & $F(3,129), p$ \\
\hline \multicolumn{6}{|l|}{ Physiological features } \\
\hline Felt shivers & $5.25^{\mathrm{F}}$ & $5.45^{\mathrm{F}}$ & $7.94^{\mathrm{S} ; \mathrm{J} ; \mathrm{A}}$ & $4.88^{\mathrm{F}}$ & $13.97,<0.001$ \\
\hline Heartbeat slowing down & $5.31^{\mathrm{J} ; \mathrm{F} ; \mathrm{A}}$ & $3.09^{\mathrm{S}}$ & $2.72^{\mathrm{S}}$ & $2.09^{\mathrm{S}}$ & $15.39,<0.001$ \\
\hline Heartbeat getting faster & $5.28^{\mathrm{J} ; \mathrm{F} ; \mathrm{A}}$ & $7.45^{\mathrm{S}}$ & $8.58^{\mathrm{S}}$ & $8.06^{\mathrm{S}}$ & $21.25,<0.001$ \\
\hline Breathing slowing down & $5.13^{\mathrm{F} ; \mathrm{A}}$ & $4.15^{\mathrm{F} ; \mathrm{A}}$ & $2.44^{\mathrm{S} ; \mathrm{J}}$ & $2.22^{\mathrm{S} ; \mathrm{J}}$ & $18.57,<0.001$ \\
\hline Breathing getting faster & $5.41^{\mathrm{F} ; \mathrm{A}}$ & $6.48^{\mathrm{F} ; \mathrm{A}}$ & $8.19^{\mathrm{S} ; \mathrm{J}}$ & $7.72^{\mathrm{S} ; \mathrm{J}}$ & $16.32,<0.001$ \\
\hline Perspired/moist hands & $4.72^{\mathrm{F} ; \mathrm{A}}$ & $5.18^{\mathrm{F} ; \mathrm{A}}$ & $8.08^{\mathrm{S} ; \mathrm{J}}$ & $7.31^{\mathrm{S} ; \mathrm{J}}$ & $30.4,<0.001$ \\
\hline Sweat & $4.16^{\mathrm{F} ; \mathrm{A}}$ & $4.76^{\mathrm{F} ; \mathrm{A}}$ & $7.97^{\mathrm{S} ; \mathrm{J}}$ & $7.06^{\mathrm{S} ; \mathrm{J}}$ & $33.02,<0.001$ \\
\hline Felt hot & $4.53^{\mathrm{F} ; \mathrm{A}}$ & $5.58^{\mathrm{A}}$ & $5.92^{\mathrm{S} ; \mathrm{A}}$ & $7.84^{\mathrm{S} ; \mathrm{J} ; \mathrm{F}}$ & $13.94,<0.001$ \\
\hline Blushed & $3.94^{\mathrm{J} ; \mathrm{A}}$ & $6.58^{\mathrm{S} ; \mathrm{F}}$ & $4.33^{\mathrm{J} ; \mathrm{A}}$ & $6.16^{\mathrm{S} ; \mathrm{F}}$ & $14.94,<0.001$ \\
\hline Felt cold & $6.09^{\mathrm{J} ; \mathrm{A}}$ & $2.39^{\mathrm{S} ; \mathrm{F}}$ & $7.03^{\mathrm{J} ; \mathrm{A}}$ & $3.66^{\mathrm{S} ; \mathrm{F}}$ & $39.45,<0.001$ \\
\hline \multicolumn{6}{|l|}{ Facial expression features } \\
\hline Smiled & $2.59^{\mathrm{J}}$ & $8.61^{\mathrm{S} ; \mathrm{F} ; \mathrm{A}}$ & $2.17^{\mathrm{J}}$ & $2.06^{\mathrm{J}}$ & $111.98,<0.001$ \\
\hline Jaw dropped & $4.53^{\mathrm{J}}$ & $6.42^{\mathrm{S}}$ & 5.53 & 5.56 & $3.56,<0.05$ \\
\hline Pressed lips together & $5.41^{\mathrm{J} ; \mathrm{A}}$ & $2.91^{\mathrm{S} ; \mathrm{F} ; \mathrm{A}}$ & $6.03^{\mathrm{J}}$ & $7.34^{\mathrm{J} ; \mathrm{S}}$ & $31.05,<0.001$ \\
\hline Eyebrows went up & $3.97^{\mathrm{J} ; \mathrm{F} ; \mathrm{A}}$ & $6.33^{\mathrm{S}}$ & $6.56^{\mathrm{S}}$ & $5.59^{\mathrm{S}}$ & $8.71,<0.001$ \\
\hline Frowned & $7.34^{\mathrm{J} ; \mathrm{F}}$ & $2.09^{\mathrm{S} ; \mathrm{F} ; \mathrm{A}}$ & $5.89^{\mathrm{J} ; \mathrm{A}}$ & $7.59^{\mathrm{J} ; \mathrm{F}}$ & $70.59,<0.001$ \\
\hline Closed his or her eyes & $6.94^{\mathrm{J}}$ & $4.39^{\mathrm{S} ; \mathrm{F}}$ & $6.72^{\mathrm{J}}$ & 5.56 & $9.27,<0.001$ \\
\hline Opened his or her eyes widely & $4.25^{\mathrm{J} ; \mathrm{F} ; \mathrm{A}}$ & $7.61^{\mathrm{S}}$ & $7.64^{\mathrm{S}}$ & $6.84^{\mathrm{S}}$ & $25.06,<0.001$ \\
\hline Showed tears & $8.16^{\mathrm{J} ; \mathrm{A}}$ & $6.33^{\mathrm{S}}$ & 7.03 & $6.84^{\mathrm{S}}$ & $5.6,<0.01$ \\
\hline \multicolumn{6}{|l|}{ Body movement features } \\
\hline Abrupt bodily movements & $4.69^{\mathrm{J} ; \mathrm{F} ; \mathrm{A}}$ & $6.33^{\mathrm{S}}$ & $7.00^{\mathrm{S}}$ & $7.41^{\mathrm{S}}$ & $11.48,<0.001$ \\
\hline Moved towards people or things & $4.69^{\mathrm{J} ; \mathrm{A}}$ & $6.33^{\mathrm{S} ; \mathrm{F}}$ & $7.00^{\mathrm{J}}$ & $7.41^{\mathrm{S}}$ & $7.18,<0.001$ \\
\hline Withdrew from people or things & $6.16^{\mathrm{J}}$ & $2.70^{\mathrm{S} ; \mathrm{F} ; \mathrm{A}}$ & $6.00^{\mathrm{J}}$ & $4.91^{\mathrm{J}}$ & $18.76,<0.001$ \\
\hline \multicolumn{6}{|l|}{ Paralinguistic features } \\
\hline Increased the volume of voice & $4.34^{\mathrm{J} ; \mathrm{F} ; \mathrm{A}}$ & $7.30^{\mathrm{S}}$ & $6.67^{\mathrm{S} ; \mathrm{A}}$ & $7.94^{\mathrm{S} ; \mathrm{F}}$ & $21.36,<0.001$ \\
\hline Decreased the volume of voice & $6.63^{\mathrm{J} ; \mathrm{F} ; \mathrm{A}}$ & $2.94^{\mathrm{S} ; \mathrm{F}}$ & $4.89^{\mathrm{S} ; \mathrm{J}}$ & $4.06^{\mathrm{S}}$ & $16.18,<0.001$ \\
\hline Had a trembling voice & $7.72^{\mathrm{J}}$ & $5.45^{\mathrm{S} ; \mathrm{F} ; \mathrm{A}}$ & $8.03^{\mathrm{J}}$ & $6.94^{\mathrm{J}}$ & $13.39,<0.001$ \\
\hline Had an assertive voice & $3.78^{\mathrm{J} ; \mathrm{F} ; \mathrm{A}}$ & $5.88^{\mathrm{S} ; \mathrm{A}}$ & $5.19^{\mathrm{S} ; \mathrm{A}}$ & $7.63^{\mathrm{S} ; \mathrm{J} ; \mathrm{F}}$ & $17.95,<0.001$ \\
\hline Changed melody of speech & 6.59 & 7.45 & 7.03 & 7.22 & $1.28, \mathrm{n} . \mathrm{s}$. \\
\hline Produced speech disturbances & $6.84^{\mathrm{J}}$ & $5.42^{\mathrm{S} ; \mathrm{F} ; \mathrm{A}}$ & $7.19^{\mathrm{J}}$ & $7.09^{\mathrm{J}}$ & $5.49,<0.01$ \\
\hline Spoke faster & $4.44^{\mathrm{J} ; \mathrm{F} ; \mathrm{A}}$ & $7.03^{\mathrm{S}}$ & $6.69^{\mathrm{S}}$ & $7.09^{\mathrm{S}}$ & $11.74,<0.001$ \\
\hline Spoke slower & $7.06^{\mathrm{J} ; \mathrm{F} ; \mathrm{A}}$ & $3.76^{\mathrm{S}}$ & $4.58^{\mathrm{S}}$ & $3.97^{\mathrm{S}}$ & $17.04,<0.001$ \\
\hline \multicolumn{6}{|l|}{ Linguistic features } \\
\hline Fell silent & $7.66^{\mathrm{A} ; \mathrm{J}}$ & $3.15^{\mathrm{A} ; \mathrm{F} ; \mathrm{S}}$ & $7.14^{\mathrm{J} ; \mathrm{A}}$ & $4.84^{\mathrm{S} ; \mathrm{J} ; \mathrm{F}}$ & $36.8,<0.001$ \\
\hline Produced a short utterance & $6.06^{\mathrm{J}}$ & $4.64^{\mathrm{S} ; \mathrm{F} ; \mathrm{A}}$ & $6.72^{\mathrm{J}}$ & $6.81^{\mathrm{J}}$ & $8.28,<0.001$ \\
\hline Produced a long utterance & $4.66^{\mathrm{J} ; \mathrm{A}}$ & $6.12^{\mathrm{S}}$ & 5.31 & $6.34^{\mathrm{S}}$ & $4.9,<0.01$ \\
\hline \multicolumn{6}{|l|}{ Other } \\
\hline Wanted to sing and dance & $2.88^{\mathrm{J} ; \mathrm{A}}$ & $8.09^{\mathrm{S} ; \mathrm{F} ; \mathrm{A}}$ & $2.00^{\mathrm{J}}$ & $1.69^{\mathrm{S} ; \mathrm{J}}$ & $94.14,<0.001$ \\
\hline
\end{tabular}

$52.9 \%$ of the variance, the second dimension (power) for $15.5 \%$, the third dimension (arousal) for $8.3 \%$ and the last dimension (novelty) for $5.1 \%$. A sensory cue GRID feature was included in a dimension if it achieved a 0.6 loading on this dimension (see "Appendix 2" for loadings of sensory cue GRID features on dimensions). The valence dimension is characterised by appraisals of intrinsic pleasure and goal conduciveness. Other features include action tendencies of approach versus avoidance, and pleasant emotions versus unpleasant emotions (valence sensory cue features in the present study: felt cold, smiled, pressed lips together, frowned, moved towards people or things, withdrew from people or things, had a trembling voice, produced a short utterance, produced a long 
Table 2 Means and statistics for Smutek, Radość, Strach, Ztość and Gniew on selected behavioural expression and body activity GRID Features

\begin{tabular}{|c|c|c|c|c|c|c|}
\hline \multirow[t]{2}{*}{ Feature } & \multicolumn{6}{|l|}{ Means } \\
\hline & Smutek & Radość & Strach & Ztość & Gniew & $F(4,124), p$ \\
\hline \multicolumn{7}{|l|}{ Physiological features } \\
\hline Felt shivers & $4.24^{\mathrm{St}}$ & $5.15^{\mathrm{St}}$ & $7.19^{\mathrm{Sm} ; \mathrm{R} ; \mathrm{Z} ; \mathrm{G}}$ & $5.26^{\mathrm{St}}$ & $5.5^{\mathrm{St}}$ & $5.75,<0.001$ \\
\hline Heartbeat slowing down & $6.52^{\mathrm{R} ; \mathrm{St} ; \mathrm{Z} ; \mathrm{G}}$ & $3.00^{\mathrm{Sm}}$ & $2.94^{\mathrm{Sm}}$ & $2.21^{\mathrm{Sm}}$ & $2.70^{\mathrm{Sm}}$ & $11.3,<0.001$ \\
\hline Heartbeat getting faster & $3.52^{\mathrm{R} ; \mathrm{St} ; \mathrm{Z} ; \mathrm{G}}$ & $7.30^{\mathrm{Sm}}$ & $8.50^{\mathrm{Sm}}$ & $7.89^{\mathrm{Sm}}$ & $7.83^{\mathrm{Sm}}$ & $24.49,<0.001$ \\
\hline Breathing slowing down & $6.33^{\mathrm{R} ; \mathrm{St} ; \mathrm{Z} ; \mathrm{G}}$ & $3.44^{\mathrm{Sm} ; \mathrm{Z}}$ & $2.66^{\mathrm{Sm}}$ & $1.32^{\mathrm{Sm} ; \mathrm{R}}$ & $2.93^{\mathrm{Sm}}$ & $14.33,<0.001$ \\
\hline Breathing getting faster & $3.10^{\mathrm{R} ; \mathrm{St} ; \mathrm{Z} ; \mathrm{G}}$ & $6.52^{\mathrm{Sm} ; \mathrm{St} ; \mathrm{Z} ; \mathrm{G}}$ & $8.31^{\mathrm{Sm} ; \mathrm{R} ;}$ & $8.68^{\mathrm{Sm} ; \mathrm{R}}$ & $7.97^{\mathrm{Sm} ; \mathrm{R}}$ & $47.77,<0.001$ \\
\hline Perspired/moist hands & $3.24^{\mathrm{St} ; \mathrm{Z} ; \mathrm{G}}$ & $4.81^{\mathrm{St} ; \mathrm{G}}$ & $7.75^{\mathrm{Sm} ; \mathrm{R}}$ & $6.00^{\mathrm{Sm}}$ & $6.97^{\mathrm{Sm} ; \mathrm{R}}$ & $16.07,<0.001$ \\
\hline Sweat & $2.67^{\mathrm{St} ; \mathrm{Z} ; \mathrm{G}}$ & $3.89^{\mathrm{St} ; \mathrm{Z} ; \mathrm{G}}$ & $7.84^{\mathrm{Sm} ; \mathrm{R}}$ & $6.11^{\mathrm{Sm} ; \mathrm{R}}$ & $7.20^{\mathrm{Sm} ; \mathrm{R}}$ & $23.29,<0.001$ \\
\hline Felt hot & $2.33^{\mathrm{R} ; \mathrm{St} ; \mathrm{Z} ; \mathrm{G}}$ & $5.70^{\mathrm{Sm} ; \mathrm{Z} ; \mathrm{G}}$ & $6.91^{\mathrm{Sm}}$ & $8.37^{\mathrm{Sm} ; \mathrm{R}}$ & $7.87^{\mathrm{Sm} ; \mathrm{R}}$ & $31.59,<0.001$ \\
\hline Blushed & $2.24^{\mathrm{R} ; \mathrm{Z} ; \mathrm{G}}$ & $6.78^{\mathrm{SmSt}}$ & $3.22^{\mathrm{R} ; \mathrm{Z} ; \mathrm{G}}$ & $6.21^{\mathrm{Sm} ; \mathrm{St}}$ & $6.50^{\mathrm{Sm} ; \mathrm{St}}$ & $21.61,<0.001$ \\
\hline Felt cold & $6.67^{\mathrm{R} ; \mathrm{Z}}$ & $2.15^{\mathrm{Sm} ; \mathrm{St} ; \mathrm{G}}$ & $6.16^{\mathrm{R} ; \mathrm{Z}}$ & $3.00^{\mathrm{Sm} ; \mathrm{St}}$ & $4.83^{\mathrm{R}}$ & $14.11,<0.001$ \\
\hline \multicolumn{7}{|l|}{ Facial expression features } \\
\hline Smiled & $1.81^{\mathrm{R}}$ & $8.52^{\mathrm{Sm} ; \mathrm{St} ; \mathrm{Z} ; \mathrm{G}}$ & $1.47^{\mathrm{R}}$ & $1.58^{\mathrm{R}}$ & $1.70^{\mathrm{R}}$ & $126.49,<0.001$ \\
\hline Jaw dropped & 3.86 & 3.81 & 3.22 & 3.26 & 3.47 & 0.34, n. s. \\
\hline Pressed lips together & $6.00^{\mathrm{R} ; \mathrm{Z}}$ & $2.30^{\mathrm{Sm} ; \mathrm{St} ; \mathrm{Z} . \mathrm{G}}$ & $5.47^{\mathrm{R} ; \mathrm{Z} ; \mathrm{G}}$ & $8.47^{\mathrm{Sm} ; \mathrm{R} ; \mathrm{St}}$ & $7.40^{\mathrm{R} ; \mathrm{St}}$ & $24.1,<0.001$ \\
\hline Eyebrows went up & $2.43^{\mathrm{R} ; \mathrm{Z} ; \mathrm{G}}$ & $4.74^{\mathrm{Sm}}$ & 4.41 & $5.11^{\mathrm{Sm}}$ & $4.97^{\mathrm{Sm}}$ & $3.87,<0.001$ \\
\hline Frowned & $4.38^{\mathrm{R} ; \mathrm{Z} ; \mathrm{G}}$ & $2.41^{\mathrm{Sm} ; \mathrm{Z} ; \mathrm{G}}$ & $3.78^{\mathrm{Z} ; \mathrm{G}}$ & $8.58^{\mathrm{Sm} ; \mathrm{R} ; \mathrm{St}}$ & $7.07^{\mathrm{Sm} ; \mathrm{R} ; \mathrm{St}}$ & $34.31,<0.001$ \\
\hline Closed his or her eyes & $7.67^{\mathrm{R} ; \mathrm{Z} ; \mathrm{G}}$ & $4.63^{\mathrm{Sm}}$ & 6.47 & $4.47^{\mathrm{Sm}}$ & $5.47^{\mathrm{Sm}}$ & $5.61,<0.001$ \\
\hline Opened his or her eyes widely & $2.10^{\mathrm{R} ; \mathrm{St} ; \mathrm{G}}$ & $6.85^{\mathrm{Sm} ; \mathrm{Z}}$ & $7.09^{\mathrm{Sm} ; \mathrm{Z}}$ & $3.63^{\mathrm{R} ; \mathrm{St} ; \mathrm{G}}$ & $5.77^{\mathrm{Sm} ; \mathrm{Z}}$ & $23.45,<0.001$ \\
\hline Showed tears & $8.71^{\mathrm{R} ; \mathrm{St} ; \mathrm{G}}$ & $6.89^{\mathrm{Sm}}$ & $5.91^{\mathrm{Sm}}$ & 7.00 & $6.33^{\mathrm{Sm}}$ & $5.44,<0.001$ \\
\hline \multicolumn{7}{|l|}{ Body movement features } \\
\hline Abrupt bodily movements & $2.81^{\mathrm{R} ; \mathrm{St} ; \mathrm{Z} ; \mathrm{G}}$ & $6.56^{\mathrm{Sm}}$ & $6.22^{\mathrm{Sm} ; \mathrm{Z} ; \mathrm{G}}$ & $7.95^{\mathrm{Sm} ; \mathrm{St}}$ & $8.07^{\mathrm{Sm} ; \mathrm{St}}$ & $22.28,<0.001$ \\
\hline Moved towards people or things & $2.86^{\mathrm{R}}$ & $6.81^{\mathrm{Sm} ; \mathrm{St} ; \mathrm{G}}$ & $4.50^{\mathrm{R}}$ & 5.00 & $4.80^{\mathrm{R}}$ & $7.2,<0.001$ \\
\hline Withdrew from people or things & $7.10^{\mathrm{R} ; \mathrm{Z}}$ & $1.96^{\mathrm{Sm} ; \mathrm{St} ; \mathrm{Z} ; \mathrm{G}}$ & $6.34^{\mathrm{R} ; \mathrm{Z}}$ & $4.37^{\mathrm{Sm} ; \mathrm{R} ; \mathrm{St}}$ & $5.53^{\mathrm{R}}$ & $19.0,<0.001$ \\
\hline \multicolumn{7}{|l|}{ Paralinguistic features } \\
\hline Increased the volume of voice & $2.00^{\mathrm{R} ; \mathrm{St} ; \mathrm{Z} ; \mathrm{G}}$ & $7.74^{\mathrm{Sm} ; \mathrm{St}}$ & $4.84^{\mathrm{Sm} ; \mathrm{R} ; \mathrm{Z} ; \mathrm{G}}$ & $8.05^{\mathrm{Sm} ; \mathrm{St}}$ & $8.43^{\mathrm{Sm} ; \mathrm{St}}$ & $50.08,<0.001$ \\
\hline Decreased the volume of voice & $6.81^{\mathrm{R} ; \mathrm{St} ; \mathrm{Z} ; \mathrm{G}}$ & $3.37^{\mathrm{Sm} ; \mathrm{Z}}$ & $2.88^{\mathrm{Sm}}$ & $1.42^{\mathrm{Sm} ; \mathrm{R}}$ & $2.20^{\mathrm{Sm}}$ & $22.32,<0.001$ \\
\hline Had a trembling voice & $8.05^{\mathrm{R}}$ & $5.63^{\mathrm{Sm} ; \mathrm{St}}$ & $7.97^{\mathrm{R}}$ & 6.16 & 6.53 & $5.69,<0.001$ \\
\hline Had an assertive voice & $1.90^{\mathrm{R} ; \mathrm{Z} ; \mathrm{G}}$ & $5.07^{\mathrm{Sm} ; \mathrm{St} ; \mathrm{Z} ; \mathrm{G}}$ & $3.06^{\mathrm{R} ; \mathrm{Z} ; \mathrm{G}}$ & $7.32^{\mathrm{Sm} ; \mathrm{R} ; \mathrm{St}}$ & $7.97^{\mathrm{Sm} ; \mathrm{R} ; \mathrm{St}}$ & $45.64,<0.001$ \\
\hline Changed melody of speech & 7.81 & 7.19 & 7.56 & 8.42 & 8.07 & 2.01, n. s. \\
\hline Produced speech disturbances & 7.52 & 6.15 & 7.56 & 6.79 & 7.13 & 2.13, n. s. \\
\hline Spoke faster & $2.90^{\mathrm{R} ; \mathrm{St} ; \mathrm{Z} ; \mathrm{G}}$ & $7.41^{\mathrm{Sm}}$ & $6.00^{\mathrm{Sm} ; \mathrm{Z} ; \mathrm{G}}$ & $8.16^{\mathrm{Sm} ; \mathrm{St}}$ & $7.67^{\mathrm{Sm} ; \mathrm{St}}$ & $23.55,<0.001$ \\
\hline Spoke slower & $7.33^{\mathrm{R} ; \mathrm{St} ; \mathrm{Z} ; \mathrm{G}}$ & $2.70^{\mathrm{Sm} ; \mathrm{St}}$ & $4.97^{\mathrm{Sm} ; \mathrm{R} ; \mathrm{Z}}$ & $1.79^{\mathrm{Sm} ; \mathrm{St} ; \mathrm{G}}$ & $3.67^{\mathrm{Sm} ; \mathrm{Z}}$ & $22.29,<0.001$ \\
\hline \multicolumn{7}{|l|}{ Linguistic features } \\
\hline Fell silent & $8.24^{\mathrm{R} ; \mathrm{Z} ; \mathrm{G}}$ & $2.81^{\mathrm{Sm} ; \mathrm{St} ; \mathrm{G}}$ & $6.59^{\mathrm{R} ; \mathrm{Z}}$ & $4.16^{\mathrm{Sm} ; \mathrm{St}}$ & $5.97^{\mathrm{Sm} ; \mathrm{R}}$ & $17.0,<0.001$ \\
\hline Produced a short utterance & $7.24^{\mathrm{R} ; \mathrm{St}}$ & $3.48^{\mathrm{Sm} ; \mathrm{G}}$ & $5.03^{\mathrm{Sm}}$ & 5.16 & $6.10^{\mathrm{R}}$ & $8.38,<0.001$ \\
\hline Produced a long utterance & $3.95^{\mathrm{R} ; \mathrm{G}}$ & $6.07^{\mathrm{Sm} ; \mathrm{St}}$ & $3.34^{\mathrm{R} ; \mathrm{Z} ; \mathrm{G}}$ & $5.79^{\mathrm{St}}$ & $6.27^{\mathrm{Sm} ; \mathrm{St}}$ & $9.6,<0.001$ \\
\hline \multicolumn{7}{|l|}{ Other } \\
\hline Wanted to sing and dance & $1.19^{\mathrm{R}}$ & $8.15^{\mathrm{Sm} ; \mathrm{St} ; \mathrm{Z} ; \mathrm{G}}$ & $1.69^{\mathrm{R}}$ & $1.32^{\mathrm{R}}$ & $2.37^{\mathrm{R}}$ & $84.34,<0.001$ \\
\hline
\end{tabular}

Significant differences between the means are denoted by the first letters of the emotions: ${ }^{\mathrm{Sm}}{ }_{\text {smutek, }}{ }^{\mathrm{R}}$ radość, ${ }^{\mathrm{St}}$ strach, ${ }^{\mathrm{Z}}$ ztosśc and ${ }^{\mathrm{G}}$ gniew

utterance, produced speech disturbances, wanted to sing or dance). Power includes appraisals of control, leading to feelings of power and weakness. It is also characterised by appraisals of interpersonal dominance or submission (power sensory cue features in the present study: closed his or her eyes, increased the volume of voice, decreased the volume of voice, had an assertive voice, fell silent, spoke faster, spoke slower). The arousal dimension is mainly characterised by sympathetic arousal (arousal sensory cue features in the present study: felt shivers, heartbeat slowing 
Table 3 Means and $t$ test results for sadness versus smutek

\begin{tabular}{|c|c|c|c|c|c|}
\hline Feature & $\begin{array}{l}\text { British } \\
\text { English } \\
\text { mean }\end{array}$ & $\begin{array}{l}\text { Polish } \\
\text { mean }\end{array}$ & $t$ & $d f$ & $p$ \\
\hline Heartbeat getting faster & 5.28 & 3.52 & -2.66 & 51 & $<0.01$ \\
\hline Breathing getting faster & 5.41 & 3.1 & -4.02 & 51 & $<0.01$ \\
\hline Perspired/moist hands & 4.72 & 3.24 & -2.72 & 51 & $<0.01$ \\
\hline Felt hot & 4.53 & 2.33 & -4.07 & 51 & $<0.01$ \\
\hline Blushed & 3.94 & 2.24 & -3.14 & 51 & $<0.01$ \\
\hline Frowned & 7.34 & 4.38 & -4.68 & 27.91 & $<0.01$ \\
\hline $\begin{array}{l}\text { Opened his or her eyes } \\
\text { widely }\end{array}$ & 4.25 & 2.1 & -4.7 & 48.93 & $<0.01$ \\
\hline $\begin{array}{l}\text { Abrupt bodily } \\
\text { movements }\end{array}$ & 4.69 & 2.81 & -3.02 & 51 & $<0.01$ \\
\hline $\begin{array}{l}\text { Moved towards people or } \\
\text { things }\end{array}$ & 5.47 & 2.86 & -4.02 & 51 & $<0.01$ \\
\hline $\begin{array}{l}\text { Increased the volume of } \\
\text { voice }\end{array}$ & 4.34 & 2.0 & -4.6 & 49.66 & $<0.01$ \\
\hline Had an assertive voice & 3.78 & 1.9 & -4.34 & 50.96 & $<0.01$ \\
\hline Wanted to sing and dance & 2.88 & 1.19 & -3.66 & 34.79 & $<0.01$ \\
\hline
\end{tabular}

Table 4 Means and $t$ test results for joy versus radość

\begin{tabular}{llllll}
\hline Feature & $\begin{array}{l}\text { British } \\
\text { English mean }\end{array}$ & $\begin{array}{l}\text { Polish } \\
\text { mean }\end{array}$ & $t$ & $d f$ & $p$ \\
\hline Jaw dropped & 6.42 & 3.81 & -4.2 & 58 & $<0.01$ \\
\hline
\end{tabular}

down, heartbeat getting faster, breathing slowing down, breathing getting faster, perspired/moist hands, sweat, felt hot, abrupt bodily movements). The fourth dimension is represented by novelty. On this dimension, appraisals of novelty and unpredictability are compared with expectedness or familiarity (novelty sensory cue features in the present study: jaw dropped, eyebrows went up, opened his or her eyes widely). Three of the GRID features, blushed, showed tears and changed melody of speech, were not included in any of the four dimensions as they had loadings less than 0.6 on all of these.

It must be stressed that there are other GRID features that load on each of the four dimensions apart from the features presented above. However, these were not selected in the present study because they did not comprise the sensory cue elements that could be encoded by socially interactive robots. As the GRID questionnaire is suited to provide a precise characterisation of the dimensional values of the various emotions and the statistical differences between the languages, the extent to which each of the
Table 5 Means and $t$ test results for fear versus strach

\begin{tabular}{|c|c|c|c|c|c|}
\hline Feature & $\begin{array}{l}\text { British } \\
\text { English } \\
\text { mean }\end{array}$ & $\begin{array}{l}\text { Polish } \\
\text { mean }\end{array}$ & $t$ & $d f$ & $p$ \\
\hline Jaw dropped & 5.53 & 3.22 & -3.69 & 66 & $<0.01$ \\
\hline Eyebrows went up & 6.56 & 4.41 & -3.67 & 58.52 & $<0.01$ \\
\hline Frowned & 5.89 & 3.78 & -3.72 & 57.68 & $<0.01$ \\
\hline $\begin{array}{l}\text { Increased the volume of } \\
\text { voice }\end{array}$ & 6.67 & 4.84 & -2.87 & 55.06 & $<0.01$ \\
\hline $\begin{array}{l}\text { Decreased the volume of } \\
\text { voice }\end{array}$ & 4.89 & 2.88 & -3.52 & 66 & $<0.01$ \\
\hline Had an assertive voice & 5.19 & 3.06 & -3.87 & 66 & $<0.01$ \\
\hline $\begin{array}{l}\text { Produced a short } \\
\text { utterance }\end{array}$ & 6.72 & 5.03 & -3.12 & 49.42 & $<0.01$ \\
\hline $\begin{array}{l}\text { Produced a long } \\
\text { utterance }\end{array}$ & 5.31 & 3.34 & -3.67 & 66 & $<0.01$ \\
\hline
\end{tabular}

dimensions can be represented by a reduced number of sensory cue features is uncertain. The results of the present study should therefore be viewed as initial indications about the overall dimensionality of the respective emotions in English and Polish, which would merit further investigation and confirmation.

\section{Analyses and Results}

Intra-linguistic and inter-linguistic analyses were performed on the GRID data. For both of these, the results are grouped and presented in Tables 1, 2, 3, 4, 5 and 6 on the basis of emotions in the following order: sadness, joy, fear and anger. It was decided that anger should be presented last as it is potentially the least equivalent between Polish and British English on account of the two distinct Polish concepts, złość and gniew.

Intra-Linguistic Analyses

Two separate MANOVAs were performed on the British English and Polish GRID samples. For both British English and Polish, the dependent variables were the thirty-three behavioural expression/body activity features (see Tables 1 and 2). The independent variable for British English was emotion (sadness, joy, fear and anger), with the dependent variable for Polish also being emotion (smutek, radość, strach, złość and gniew). There was a significant interaction between emotion and behavioural expression/body activity features for both British English ( $F$ (33, $99)=8.83, p<0.01)$ and Polish $(F(33,132)=7.14$, $p<0.01$ ), showing that the differences between the 
Table 6 Means and $t$ test results for anger versus ztość and anger versus gniew

\begin{tabular}{|c|c|c|c|c|c|c|}
\hline Feature & $\begin{array}{l}\text { Anger } \\
\text { mean }\end{array}$ & $\begin{array}{l}\text { Złość } \\
\text { mean }\end{array}$ & $\begin{array}{l}\text { Gniew } \\
\text { mean }\end{array}$ & $t$ & $d f$ & $p$ \\
\hline $\begin{array}{l}\text { Breathing } \\
\text { slowing } \\
\text { down }\end{array}$ & 2.22 & 1.32 & & -2.81 & 47.36 & $<0.01$ \\
\hline $\begin{array}{l}\text { Breathing } \\
\text { getting faster }\end{array}$ & 7.72 & 8.68 & & 2.98 & 38.4 & $<0.01$ \\
\hline Jaw dropped & $5.56^{\mathrm{ab}}$ & $3.26^{\mathrm{a}}$ & $3.47^{\mathrm{b}}$ & $\begin{array}{l}-3.44^{\mathrm{a}} \\
-3.5^{\mathrm{b}}\end{array}$ & $\begin{array}{l}49^{\mathrm{a}} \\
60^{\mathrm{b}}\end{array}$ & $\begin{array}{l}<0.01^{\mathrm{a}} \\
<0.01^{\mathrm{b}}\end{array}$ \\
\hline $\begin{array}{l}\text { Pressed lips } \\
\text { together }\end{array}$ & 7.34 & 8.47 & & 2.73 & 49 & $<0.01$ \\
\hline Frowned & 7.59 & 8.58 & & 3.04 & 47.92 & $<0.01$ \\
\hline $\begin{array}{l}\text { Opened his or } \\
\text { her eyes } \\
\text { widely }\end{array}$ & 6.84 & 3.63 & & -4.25 & 28.86 & $<0.01$ \\
\hline $\begin{array}{l}\text { Moved } \\
\text { towards } \\
\text { people or } \\
\text { things }\end{array}$ & $7.16^{\mathrm{ab}}$ & $5.0^{\mathrm{a}}$ & $4.8^{\mathrm{b}}$ & $\begin{array}{r}3.07^{\mathrm{a}} \\
-4.2^{\mathrm{b}}\end{array}$ & $\begin{array}{l}24.34^{\mathrm{a}} \\
45.23^{\mathrm{b}}\end{array}$ & $\begin{array}{l}<0.01^{\mathrm{a}} \\
<0.01^{\mathrm{b}}\end{array}$ \\
\hline $\begin{array}{l}\text { Decreased the } \\
\text { volume of } \\
\text { voice }\end{array}$ & $4.06^{\mathrm{ab}}$ & $1.42^{\mathrm{a}}$ & $2.2^{\mathrm{b}}$ & $\begin{array}{l}-5.53^{\mathrm{a}} \\
-3.39^{\mathrm{b}}\end{array}$ & $\begin{array}{l}44.64^{\mathrm{a}} \\
59.16^{\mathrm{b}}\end{array}$ & $\begin{array}{l}<0.01^{\mathrm{a}} \\
<0.01^{\mathrm{b}}\end{array}$ \\
\hline $\begin{array}{l}\text { Changed } \\
\text { melody of } \\
\text { speech }\end{array}$ & 7.22 & 8.42 & & 2.91 & 48.36 & $<0.01$ \\
\hline Spoke slower & 3.97 & 1.79 & & -4.36 & 48.86 & $<0.01$ \\
\hline
\end{tabular}

a means and $t$ test results for anger versus ztość

$\mathrm{b}$ means and $t$ test results for anger versus gniew

emotions were therefore dependent on the behavioural expression/body activity features for both languages. The univariate effects for each of the behavioural expression/ body activity features are shown in the last column of Table 1 (British English) and Table 2 (Polish). For features that violated homogeneity of variance on Levene's test of equality of error variance, a more stringent $\alpha$ level was set at 0.01 (cf. [29]). The Tukey HSD post hoc test was performed on the emotions in both British English and Polish. Significant differences between the British English emotions (Table 1) are shown by superscripted letters to the right of the means that denote each of the emotions as follows: sadness $={ }^{\mathrm{S}}$, joy $={ }^{\mathrm{J}}$, fear $={ }^{\mathrm{F}}$ and anger $={ }^{\mathrm{A}}$; and similarly for the Polish means (Table 2) as follows: smutek $={ }^{\mathrm{Sm}}, \quad$ radość $={ }^{\mathrm{R}}$, strach $={ }^{\mathrm{St}}, \quad$ złość $={ }^{\mathrm{Z}}$ and gniew $={ }^{\mathrm{G}}$. For example, in Table 1 , the felt shivers feature shows $5.25^{\mathrm{F}}$ in the column for sadness column, $5.45^{\mathrm{F}}$ in the column for joy, $7.94^{\mathrm{S} ; \mathrm{J} ; \mathrm{A}}$ in the column for fear and $4.88^{\mathrm{F}}$ in the column for anger. This means that felt shivers is significantly more likely to occur for fear than sadness, joy and anger.
Inter-Linguistic Analyses

Five independent $t$ tests were performed between the equivalent emotions in British English and Polish (sadness-smutek, joy-radość, fear-strach, anger-ztość and anger-gniew). To ensure that the cumulative Type 1 error was below 0.05 , the Bonferroni correction was applied, resulting in an $\alpha$ level of 0.01 . Tables 3, 4, 5 and 6 show the means for the behavioural expression/body activity features where there were significant differences between British English and Polish.

The results of these intra- and inter-linguistic analyses are presented for the Polish and British English equivalents of each of the emotions in separate sections below.

\section{Sadness (British English Sadness and Polish Smutek)}

\section{GRID Results}

Tables 1 and 2 show that relative to the other emotions both British English sadness and Polish smutek are characterised by lower arousal (e.g. slower heartbeat and breathing, and less sweating). However, the significantly lower values for heartbeat getting faster, breathing getting faster and felt hot presented in Table 3 for smutek suggest that although this emotion is less activated in both languages, it is more so in Polish. As expected, power is also lower in both of these emotions, as evidenced by the linguistic and paralinguistic features decreased the volume of voice, fell silent and spoke slower. Smutek is somewhat lower in power compared with sadness (see increased the volume of voice and had an assertive voice, Table 3), showing that despite power being low in both languages, it is to some extent lower in Polish. The negative valence that is characteristic of sadness and smutek is shown by the less likelihood of smiling, relatively more withdrawal from people or things, and feeling cold in Tables 1 and 2. Although negative valence characterises both sadness and smutek, the relative valence between these two emotions is less clear, with significantly higher ratings for sadness on both the positively valenced features of moved towards and sing and dance and the negatively valenced feature of frowned (Table 3). There is also evidence that sadness and smutek, relative to the other emotions, are more predictable, as shown by the relatively low scores on opened his or her eyes widely and eyebrows went up in Tables 1 and 2, with smutek having more of an element of predictability than sadness, as shown in Table 3 by the lower likelihood of the opening of eyes. 


\section{Corpus Analysis Results}

Language corpus analysis results shed more light on the properties identified in the GRID questionnaire. Frequencies of occurrence of language-specific Part-Of-Speech (POS) patterns involving emotion words provide further information with respect to the properties of culturally bound emotion concepts and their linguistic expression. The corpus data are either fully or partly formalizable in terms of componential and cluster analyses. Frequencies of occurrence of the linguistic realisation of a particular emotion or emotion clusters in the two languages can be juxtaposed to the associated valence, arousal and dominance values of the emotion words, involving aggregates of
(3) her hands, for once, lying idle in her lap, an expression of infinite sadness on her face

(4) let out a terrible call and shriek of sadness

SMUTEK 'sadness' concordances

(5) Smutek na twarzy 'sadness on face'

(6) Anders pokiwał ze smutkiem głową 'Anders nodded his head with sadness'

In addition to the bodily reactions involving the emotion of sadness, concordances can reveal a range of shades of the emotion, by using relevant modifying phrases such as great, gentle, rich, full, extreme, enormous, dull, dignified and deep:

\section{N Concordance \\ 79 you?' 'Rarely. Only in moments of great sadness or loneliness. But the taste of \\ 80 of Gruner. Perhaps despite great sadness to read a few paragraphs of this \\ 81 bonhomie, mixed with a hint of gentle sadness, which quite eludes the Israel \\ 82 darker, the shadows were gathering. Sadness filled her heart. She didn't know \\ 83 Varley said sadly. but it was a rich full sadness. 'Lonely old people, depressed \\ 84 These are likely to include extreme sadness and anger. The therapist should \\ 85 there, all tied up, the whole enormous sadness of a shirt. Roy Johnson said \\ 86 and there was no surprise, only a dull sadness as my lingers closed around a \\ 87 and 'I Woke Up Cryin" has a dignified sadness. 'Fletcher Henderson and the \\ 88 sat smoking. He was filled with deep sadness. He understood why Nick found}

bodily gestures as well as behavioural and language-related properties of emotions as particular tertia comparationis in the present analysis.

A characteristic feature of the English-Polish corpusbased contrasts concerning sadness (see appendices for SADNESS and SMUTEK Nouns, Adjectives, Verbs) is the more frequent collocate links between smutek and Polish adjectives expressing higher intensity (przejmujacy 'piercing, bitter', bezbrzeżny 'infinite lit. unbounded, boundless', etc.), when compared with English. Similarly, the top verbal collocations include metaphoric phrases showing a higher degree of emotion intensity in Polish than in English (pograżyć 'plunge', ogarnać 'overwhelmed (by sadness)', topić 'sunk (in sadness)', napawać 'filled with (sadness)'). Examples of English and Polish concordances identify the characteristic properties of these emotions:

SADNESS concordances

(1) The fear and great sadness are expressed through the cry and the use of shiver

(2) tears of real sadness

\section{GRID Versus Corpus Results}

The cross-cultural consistency shown between the GRID and corpora results on the power dimension suggests that this is a salient feature distinguishing between Polish and British English sadness. The GRID results showing an element of lower power in smutek compared with sadness (increased the volume of voice and had an assertive voice) are also reflected in the higher degree of emotion intensity in Polish metaphoric phrases than in English (pograżyć 'plunge', ogarnać 'overwhelmed (by sadness)', topić 'sunk (in sadness)', napawać 'filled with (sadness)'), which clearly point to relatively lower power in Polish. Consistent with this, the concordance data for sadness refer to the letting out of 'a terrible call and shriek of sadness' - an action characterising relatively higher power. The relatively lower arousal and somewhat more predictability in smutek compared with sadness is partly supported by some corpus data, which generate przygnebienie 'depression', melancholia 'melancholy' or apatia 'apathy' as contextual collocational forms in 
Polish, while the top most emotion collocate form in English is anger.

Joy (British English Joy and Polish Radość)

\section{GRID Results}

In Tables 1 and 2, it can be seen that joy and radość are similar, positive emotions that invite social engagement (e.g. relatively high values for smiling, moving towards people or things and wanting to sing or dance, but a low score for falling silent). There is only one significant difference between these emotions (jaw dropped is higher in joy), which shows that joy (mean: 6.42) might entail relatively more surprise (Table 4) relative to radość (mean: 3.81); however, neither emotion has an extreme rating on this feature.

\section{Corpus Analysis Results}

The GRID joy results are complemented by the corpus data. The immediate context of English joy, expressed in terms of verbal collocates, indicates a strong element of bodily reaction engagement (bring, jump, experience, discover, watch, dance, share, express, ride, weep, behold, burst, fill, leap, sing, shout, kiss), while a clear feature of radość is its more social (collectivist) character (dawać 'give', przynosić 'bring', przyjać 'receive', witać 'greet', dzielic' 'share'), but also the presence of a certain amount of control (kontrolować 'control', chować/ukrywać 'hide'). Less frequent collocates of Polish radość 'joy' also include activities such as in (8); however, their frequencies are all below those in English.

(8) RADOŚć 'joy' collocates of lower frequencies

śmiech 'laugh'

skakać 'jump'

płakać 'cry'

łza 'tear'

krzyczeć 'shout'

tańczyć 'dance'

śpiewać 'sing'

klaskać 'clasp (hands)'

piszczeć 'squeal'

drżeć 'tremble'

\section{GRID Versus Corpus Results}

The corpora results add more in-depth information to the GRID findings on the comparison between joy and radość. The verbal collocates that characterise bodily reaction engagement (e.g. dance, laugh, sing, kiss and express) in both joy and radość are consistent with the social engagement action features shown in the GRID results for these emotions. However, frequencies of these bodily reaction engagement collocates are lower for radość, suggesting that joy might be characterised by more of an element of outward action and engagement than radość. This possibility is consistent with a certain amount of control (kontrolować 'control', chować/ukrywać 'hide') in the verbal collocates of radość. Verbal collocates also suggest that radość has a certain social (collectivistic) element compared with joy (e.g. dawać 'give', przynosić 'bring', przyjać 'receive', witać 'greet' and dzielić 'share').

Fear (British English Fear and Polish Strach)

\section{GRID Results}

Tables 1 and 2 show that the clearest defining characteristic of fear and strach is high arousal (e.g. felt shivers, heartbeat getting faster, breathing getting faster and sweat). However, there are no significant differences between these two emotions on this dimension. On the whole, fear and strach do not present a clear pattern in terms of novelty; however, the somewhat higher element of surprise in fear, relative to strach, can be seen in jaw dropped and eyebrows went up, which are relatively higher in fear. The overall pattern shows that fear and strach are characterised by negative valence, as evidenced by a lack of smiling, a trembling voice and not wanting to sing and dance (Tables 1, 2). However, the relative valence of these two emotions is not clear as Table 5 shows that fear has a relatively more negative valence on the features frowned and produced a short utterance, but strach has a more negative valence than fear on produced a long utterance. A comparison between these two emotions on the power dimension is also not clear as fear is relatively more likely to have a loud, assertive voice, but to also have a quieter voice than strach.

\section{Corpus Analysis Results}

Detailed semantic analysis of the meaning of corpus-based individual collocates in both languages was performed manually to identify additional bodily cues of particular emotions and to elaborate on them, e.g. the Noun collocates of Polish fear 'strach' all specify bodily reactions of Experiencer such as ze strachu ściśniętym gardtem (lit. 'with a throat squeezed/pressed with fear'), i.e. to have a lump in one's throat. The collocates also describe fear as experienced with zaciśnięte ze strachu oczy 'eyes closed (lit. pressed) with fear' or the opposite rozszerzone strachem oczy 'eyes widened with fear', as evident in the corpus data. The corpus data provide detailed support and extension of the GRID features and identify features, which 
would be considered opposite to each other when taken verbatim (eyes opened or eyes closed). However, it can be reasoned that these are justified if different fear scenarios are taken into consideration (see Lewandowska-Tomaszczyk and Wilson [18] for a discussion on different fear scenarios). Descriptions of face and facial gestures also provide more detail: zastygta $w$ strachu twarz 'face solidified in fear', ściagnieta strachem twarz 'face puckered with fear', skrzywiona ze strachu twarz lit. 'face bent/ twisted/grimaced with fear'. The GRID fear-strach results are consistent with the collocates of the fear words in both languages. Our previous analysis of fear in English and Polish [18] revealed two distinct fear scenarios: one in which fear paralyses, more frequent in Polish than English, and another where fear is controlled or conquered, more frequent in English than Polish. These results are coherent with the verbal collocates of fear and strach reported in the appendices (e.g. English [fear FIGHT scenario]: overcome, confirm, raise, lose, dismiss, dispel, ease and conquer; Polish: budzić 'wake (metaphoric)', żyć 'live', [fear FRIGHT scenario] paść 'fall down', trzaśćldrżeć 'tremble/ shake', ogarniać 'overwhelm', umierać 'die', paraliżować 'paralyse', napedzić 'urge/cause', najeść lit. '(be) eaten up' and oblecieć '(be) overwhelmed'). ${ }^{3}$

Lists of concordances provide materials concerning the Sources (Stimuli) of fear as in the list below (fear of getting lost, fear of God, etc.):

(9) FEAR concordances
Whereas the British English collocates such as overcome, dismiss, dispel and conquer suggest an energising, higher degree of power that might overcome one's fear, the Polish collocates (e.g. paść 'fall down', trzaśćldrżeć 'tremble/ shake', ogarniać 'overwhelm', umierać 'die', paraliżować 'paralyse') point to a less powerful response to fear in which the individual more passively submits to fear. The Polish-British English comparison on the power dimension in the GRID results was not consistent with this pattern. ${ }^{4}$

Anger (British English Anger and Polish Złość and Gniew)

\section{GRID Results}

It is important to assess British anger vis-à-vis the two forms of Polish anger, złość and gniew. Tables 1 and 2 clearly show that these three types of anger are high on arousal, as exemplified by faster heartbeat and breathing, and feeling hot. The faster breathing of złość in comparison with anger suggests that złość has somewhat more of an element of relatively higher arousal (see features breathing slowing down and breathing getting faster, Table 6). The features pertaining to novelty (jaw dropped, eyebrows went up, and opened his or her eyes widely) do not present a clear pattern for the three types of anger. However, despite none of these emotions being particularly associated with surprise, Table 6 shows that the dropping of the jaw is

\section{N Concordance \\ 758 wanted to take too many pictures for fear of drawing a crowd. (Why do I care? \\ 759 and Auntie Lou tiptoeing about for fear of making things worse and so \\ 760 too, without being aware of his growing fear of the day when the quiet backwater \\ 761 I still feel wary bicycling into town - fear of getting lost - because we've been \\ 762 into our classroom on tiptoes, for fear of being seen by Maureen. Then he \\ 763 like him in these parts to strike the fear of God into them. We need a few \\ 764 himself for this falling away, and the fear of bell-fire urged him to renewed}

\section{GRID Versus Corpus Results}

The noun collocates in the Polish corpus data describe fear as experienced with rozszerzone strachem oczy 'eyes widened with fear'. This suggests an element of surprise in strach, which is inconsistent with the GRID results that show a somewhat higher element of surprise in fear in comparison with strach (higher values for fear on jaw dropped and eyebrows went up). The verbal collocates in the corpora data are consistent with the fight-fright distinction that Lewandowska-Tomaszczyk and Wilson [18] observed for British English and Polish, respectively.

\footnotetext{
${ }^{3}$ The third fear scenario FLIGHT was also alluded to in [18].
}

significantly more likely to occur in anger than in both złość and gniew and the opening of the eyes is more characteristic of anger than złość. Anger, złość and gniew are characterised by relatively more negative valence (e.g. lower values on smiled, but higher values on frowned and pressed lips together). When comparing the three emotions on valence, it is evident that złość has a relatively more negative valence in comparison with anger (significant differences on three features in Table 6: ztość has higher values for pressed lips together and frowned, but a lower

\footnotetext{
${ }^{4}$ However, recall that the present study only analyses GRID features pertaining to sensory cues. Using the full spectrum of power features Lewandowska-Tomaszczyk and Wilson [18] showed that fear and strach are characterised by fight and fright, respectively.
} 
value for moved towards people or things than anger) than gniew does (a significant difference on only one feature in Table 6: gniew has a lower value than anger for moved towards people or things). Tables 1 and 2 show that anger is characterised by relatively high power (e.g. increased volume of voice, had an assertive voice, and spoke faster), with złość being somewhat relatively higher in power than anger (see lower values for ztość on decreased volume of voice and spoke slower in Table 6).

\section{Corpus Analysis Results}

The differences in distinct manifestations of anger are captured in Polish in terms of two distinct EESs, one gniew 'anger 1' and the other złość 'anger 2'. Gniew is more controllable, and is therefore easier to suppress (note ttumić 'suppress' Verbs in the collocate table) when compared with złość (no suppress Verbs), and gniew also has a more definite reason (compare Adjectives for złość bezsilny 'powerless', bezrozumny 'unreasonable, irrational, unjustified' with GNIEW stuszny 'right, rational, justified').

Gniew typically occurs when an Experiencer reacts to another person (stimulus) who directs bodily or verbal acts towards the Experiencer and is considered to be an Attacker by the Experiencer. This emotion is partly controllable and is connected with some form of reaction from the Experiencer, who aims to stop the Attacker's action. The Experiencer feels hostility or detachment as a consequence of what the Attacker did to him/her.

Złość can accompany gniew but it can also be a reaction to negative or unfavourable conditions or circumstances (Stimuli), and it is therefore a reaction of displeasure towards something and can also be related to a feeling of antagonism towards someone or irritation towards something.

Both the less frequent collocates as well as the concordances of English anger and Polish gniew 'anger 1' and ztość 'anger 2' uncover contextual characteristics of each of the emotions.

ANGER concordances

(10) His voice shook with anger

(11) Voice trembling with anger

(12) Shaking with anger

(13) His eyes flashed with anger

(14) A blaze of anger flashed across his face

(15) They both splutter with anger

(16) Emily felt anger run through her

\section{GNIEW 'anger 1' concordances}

(17) ze ściśniętą z gniewu twarzạ 'with face squeezed (tight) with anger'
(18) zadręczonạ gniewem twarzą 'face tormented with anger'

(19) w gniewie twarz zakrzepłą 'face stiffened with anger'

(20) rozdygotanym od gniewu głosem 'voice shivering with anger'

(21) kipiącym gniewem głosem 'voice boiling with anger'

(22) zduszonym/stłumionym od gniewu głosem- 'voice muffled/quashed/dampened with anger'

GNIEW 'anger 1' collocates Verbs (lower frequencies)

(23) kopnąć 'kick'

(24) krzywić 'twist'

(25) cisnać 'throw (things at sth)'

\section{złość 'anger 2' concordance}

(26) Wykrzywione złością twarze, przerażone oczy 'face grimaced (twisted, frowned) with anger, terrified eyes'

złość 'anger 2' collocates Verbs (lower frequencies)

(28) tupać 'stamp/thump one's feet'

(29) krzyczeć 'shout'

(30) syknąć 'hiss'

(31) płakać 'cry/weep'

(32) szarpnąć 'tear'

(33) prychnąć 'snart'

(34) ciskać 'throw (things) at smth'

\section{GRID Versus Corpora Results}

The collocation and concordance results for anger, złość and gniew are consistent with the GRID results as they show that these anger emotions are high on arousal and power and have a relatively more negative valence. However, although the collocation and concordance results, unlike the GRID results, do not provide a clear pattern regarding how anger, złość and gniew differ on these dimensions, they give additional information to what the GRID findings show. Further studies are necessary to uncover, for example, the possible sensory cues associated with the more controllable, easier to suppress gniew (ttumić 'suppress') in its comparison with ztość.

\section{Discussion}

GRID and corpus linguistic analyses performed on the selected expressive behavioural and body activity features 
produced profiles that one would generally expect for the basic emotions joy, sadness, fear and anger and that are consistent with those observed by Scherer and Walbott [27]. The analyses also produced interesting cross-linguistic differences between Polish and British English for each of the emotions tested.

The corpus data provide support for and enrich the GRID findings, both with reference to body movements, gestures and activities resulting from a particular emotion. The points of reference for the comparison between the GRID questionnaire results and the corpus analysis are respective body movements, gestures and activities performed by an Experiencer, usually expressed as Verbs or Verbal forms, and the emotion description and evaluation as verbalised in terms of Adjectives in the relevant linguistic materials.

\section{Intra-Linguistic Differences}

The GRID results regarding the differences between sadness, joy, fear and anger showed that there were similarities in the general contrastive pattern of these emotions within British English and within Polish. The corpus data provide additional information on emotion properties and their recognition from both intra- as well as inter-linguistic perspectives, particularly in the form of collocates with which the emotion terms are most frequently used (see "Appendix 1"). The most informative are the Verbal and Adjectival collocates, while the Noun collocations are less frequent, with a lower significance level. In two cases (sadness and joy), nominal collocations cannot be generated due to the frequencies being below the threshold level of 5 .

The pattern that emerged from the GRID analyses comparing British English sadness and the other British English emotions was similar to the one between Polish smutek and the rest of the Polish emotions. Both sadness and smutek are characterised by relatively lower arousal (e.g. slower heartbeat and breathing, and less sweating), lower power (e.g. decreased the volume of voice, fell silent and spoke slower), more negative valence (e.g. withdrawal from people or things, felt cold and less likelihood of smiling) and higher predictability (as evidenced by lower novelty-e.g. opened his or her eyes widely and eyebrows went up) than the other emotions.

The examined corpora provide additional data on sadness. English sadness corpus-generated collocations present a more moderate emotion level with the Verbal collocates feel, tinge and express. While sadness collocates most frequently with the Adjectives great and deep in our data, the Adjectival collocates of more positive emotions, like joy, are sheer, full and pure. Deep is particularly frequent with more negative emotions, as it is metaphorically linked with a lower, lying or weakened position, generally expressed as feeling down. Polish smutek 'sadness' collocates with the Adjectives of high intensity such as great, piercing, and boundless and (frequently metaphoric) Verbs of similarly negative charge (Polish equivalents to plunge/sink/drown).

Joy is generally regarded to be the opposite to sadness, and this was confirmed in the GRID results, which showed that both joy and radość, in comparison with sadness, fear and anger, are positive emotions that engender social engagement (e.g. relatively high values for smiling, moving towards people or things and wanting to sing or dance). Collocates of English joy confirm a high degree of arousal and a positive, energetic reaction to a Stimulus (jump, discover, dance, etc.). Polish radość 'joy' can be perceived in corpus data as having a more social character (first two topmost Verbal collocates are two forms of sprawiać 'give/ cause (joy)', the third being-dawać 'give'). It is also indicative of an Experiencer/Current Speaker's emotion, e.g. the form $m o ́ j$ 'my/mine' is one of the most frequently used collocates.

Similarities were also present in the comparison between fear vis-à-vis the other British English emotions and strach in relation to the other Polish emotions. These intra-linguistic comparisons showed that the most salient characteristic of both fear and strach was high arousal (e.g. heartbeat getting faster, breathing getting faster, felt shivers and sweat). These emotions were also characterised by negative valence (e.g. lack of smiling, trembling voice and not wanting to sing or dance). However, a clear pattern did not emerge for either fear and strach when they were compared with the other emotions on the novelty and power dimensions.

The relevant corpus materials are revealing in providing more details of the fear event, which turns out to belong to two distinct fear scenarios. The two scenarios identified are-a prevailing (top frequencies of collocations) one for English-a FIGHT scenario, signalled by the verbs allay, overcome, dismiss, dispel and ease and the second-less frequent in English-involving a FRIGHT scenario and expressed by raise, tremble, grow, etc. Polish strach 'fear' on the other hand is dominated by the highest frequencies of the forms indicating fear-paralysing effects, causing trembling, shivering, etc., and presents a higher preference for the FRIGHT scenario in the corpus data.

The GRID results show that, relative to the other emotions, anger, złość and gniew are all generally characterised by a pattern of relatively high arousal (e.g. faster heartbeat and breathing, and feeling hot), negative valence (e.g. relatively lower values on smiled, but higher values on frowned and pressed lips together) and high power (e.g. increased volume of voice, had an assertive voice and 
spoke faster). These results complement other similar findings (e.g. Scherer and Walbott [27]).

A striking result reported in the English ANGER collocation tables in "Appendix 1" is the feature of the Adjectival 'suppress' and Verbal meanings involving acts of venting, rising, provoking and controlling anger, which make them similar to fear on the dimension of control, with widespread eyes, sullen face/mood, emotions growing or suppressed, boiling or vented being, frequently metaphorically expressed, signs of English anger, which are parallel to and elaborate on the GRID features. Metaphor is clearly absent in the GRID questionnaire; however, it adds pertinent characteristic properties to the description of particular emotions.

Differences between Polish gniew 'anger 1' and złość 'anger 2', expressed in terms of top frequency properties related to 'justified anger' for gniew and 'powerless and unjustified anger' for ztość, provide additional evidence both for the intra-linguistic distinction between the two concepts as well as for the inter-linguistic asymmetric relation between English and Polish in this respect. Additionally, it is worth noting that while in the case of joy or fear what can be inferred from the data refers typically to either Sources/ Stimuli of emotions or to the Experiencer of emotion who is the current speaker (moja radość 'my joy'; bojaźń boża/Boga 'God's/godly fear'), in the case of gniew the Nominal and Adjectival collocates point usually to external Experiencers of emotions as in gniew boży 'God's/godly anger'.

As a whole, this background of knowledge can form a database of features that can be employed in the robotics modelling of encoding and decoding expressive sensory cues pertaining to facial expressions (e.g. Wimmer et al. [38]), motion cues (e.g. Castellano et al. [4]), vocal cues (e.g. Vogt et al. [30]) and physiological measures (e.g. Barber et al. [2]).

\section{Inter-Linguistic Differences}

Differences emerged between British English and Polish for all of the emotions. The GRID results showed that smutek has lower arousal (e.g. slower heartbeat and breathing, and a lower score for feeling hot), somewhat lower power (see relative means of increased volume of voice and had an assertive voice) and an element of more predictability (less likelihood of the opening of eyes) than sadness. The consistency between lower power in the GRID results and the lower power in Polish corpora metaphoric phrases for smutek suggests that this is a salient feature distinguishing between smutek and sadness.

The only significant difference between joy and radość in the GRID results showed that the dropping of the jaw is more likely to occur in joy, suggesting that this emotion comprises a somewhat relatively greater element of surprise, although neither emotion has an extreme rating on this feature. This is consistent with our most recent observations from our laboratory, showing that whereas surprise is conceptually closer to the happiness/joy cluster in British English, it has a more negative valence in Polish. Complementing the GRID results, the corpora results further suggest that joy is relatively more characterised by more outward action and engagement, less control and less of a social element than radość.

The only clear difference between fear and strach in the GRID results was on the novelty dimension, which showed a greater element of surprise in fear than strach (e.g. jaw dropped and eyebrows went up). However, the relatively higher element of surprise in strach as shown in rozszerzone strachem oczy 'eyes widened with fear' in the noun collocates in the Polish corpus data is inconsistent with this. The relative valence of fear and strach is not clear as fear has a relatively more negative valence thanks to the features frowned and produced a short utterance, but a more positive valence than strach as suggested by higher ratings in the feature produced a long utterance. Similar inconsistencies were seen on the power dimension, with fear being relatively more likely to have a loud, assertive voice, but to also have a quieter voice than strach. The verbal collocates in the corpora data offer a more consistent pattern regarding power, showing that whereas fear is characterised by power, dominance and control, strach is associated with relatively more weakness, submissiveness and passivity.

Turning to anger, the GRID results show that ztość has somewhat relatively higher arousal (higher ratings for breathing getting faster and lower ratings for breathing slowing down) and higher power than anger (lower values for ztość on decreased volume of voice and spoke slower). In terms of novelty, there is evidence that there is more of an element of surprise in anger than both ztość and gniew, as signified by the greater likelihood of jaw dropping in anger compared with ztość and gniew, and a more likely opening of the eyes in anger than złość. Ztość has a relatively more negative valence in comparison with anger (higher values for pressed lips together and frowned, but a lower value for moved towards people or things in Table 6) than gniew does (a significant difference on only one feature: gniew has a lower value than anger for moved towards people or things). On the whole, on the basis of the GRID results, it appears that there are more differences between anger and zlość than between anger and gniew on expressive sensory features. The corpora results do not offer support for these results pertaining to the emotion dimensions; however, they provide complementary information on the differences between Polish gniew and złość. More specifically, gniew is more controllable and easier to suppress and has more of a definite reason than ztość. 


\section{Corpus-Based Inter-Linguistic Emotion Profiles}

In the case of sadness and joy, the corpus data provide confirming evidence to the GRID results and enrich details of relevant parameters of EESs.

The GRID fear-strach results are consistent with the semantic and collocational properties of the corpus data (see appendices for FEAR and STRACH Nouns, Adjectives and Verbs), which offer further evidence in support of our previous analysis of fear in English and Polish [18], in which distinct fear scenarios were identified with a more frequent set of fear-paralysing expressions in Polish and more frequent elements showing fear-control and fear-conquering in English. The present materials point clearly to such cross-cultural differences in the linguistic data-first, English Verbal collocates include allay, overcome, lose, dismiss, dispel, ease and conquer, while Polish Verbal collocates are budzić 'wake (metaphoric)', zyć 'live', paść 'fall down', trzaść/drżeć 'tremble/shake', ogarniać 'overwhelm', umierać 'die', paralizować 'paralyse', napędzić 'urge/cause', najeść lit. '(be) eaten up' and oblecieć '(be) overwhelmed'. There are no fearcontrol Verbs in the top 15 collocates in Polish. More extensive corpus data provide additional materials, which uncover a heterogenous (polysemous, i.e. multi-meaning) character of the conceptual content of fear-strach and provide more compelling materials for three distinct scenarios in the Experiencer's fear-induced behavioural and psycho-physical properties in each of them, i.e. fright, fight and flight effects. When contrasted with Polish, we observed a prevailing fear-control pattern in the English corpus data. The analysis of fear-metaphor types presented in Lewandowska-Tomaszczyk and Wilson [18] provides additional evidence for the English preference of fight effect EESs in the corpus materials and a more frequent fright scenario in the case of Polish.

In the case of anger, two distinct concepts in Polish (gniew and złość) function as equivalents to English anger and display different collocational profiles, associated with each, which are blended in the English anger EES.

Although the results obtained from the GRID materials and from the corpus data are consistent and show a convincing picture of inter- and intra-linguistic differences in English and Polish emotions, a word of caution is needed. The results should be considered 'tentative cues' about possible differences in the overall dimensionality of the respective emotions in English and Polish, which would merit further investigation and confirmation.

The GRID and corpus results clearly show differences in emotions between Polish and British English and add weight to growing evidence showing cross-linguistic and cross-cultural differences in these and other languages (e.g. Lewandowska-Tomaszczyk \& Wilson [18], Wilson et al.
[37], Alonso-Arbiol and van der Vijer [1], Ogarkova et al. [23], and Ishii [12], as outlined above). Our demonstration of differences between Polish and British English in features pertaining to expressive, sensory cues in basic emotions that are commonly present in everyday social interactions are also consistent with recent studies showing cultural specificity regarding facial [13] and vocal [16] expression and should alert those engaged in the modelling of socially interactive robots to the need of taking such cross-linguistic and cross-cultural differences into account if such robots are to gain social competence in diverse cultures.

\section{Lessons for Emotion-Sensitive Interactive Robots}

What are the lessons arising from our study for emotionsensitive interactive robots? The first point is that there are a number features that could be detected by robots pertaining to expressive behaviours and bodily activities that accompany emotions, which when analysed as a complete profile can serve to distinguish between joy, sadness, fear, anger and other human emotions. The differences that we have found between British English and Polish are a matter of degree rather than major differences involving the presence or absence of features. For example, the observation that pressed lips is rated significantly higher for złość than for anger means that pressing the lips together is more likely to occur in złość than in anger, and not that anger is devoid of this facial display. In a similar way to a Polish individual who has had substantial experience interacting in the British culture has learnt that British anger is less likely to be accompanied by lip pressing, a robot designed to read the emotions in Polish culture must be retuned if it is to be as successful at recognising emotions in British culture. For this to happen, it is clear that further work is necessary to identify the prototypical expressive behaviour and bodily activity profiles of emotions in Poland, Britain and any other culture in which such robots will be used. In cultures where there are larger discrepancies in the cultural displays of emotion, relatively minor tuning of the feature profile might not suffice. For example, Ekman [6] noted that controlled anger in New Guineans is characterised by parted lips, which is the reverse pattern to the usual pressed lips he found for middle-class Americans. Such differences find some resonance in Wierzbicka's [35] analogy with music: " 'Anger' is not a simple key in the keyboard; it is a complex culture-specific tune. The repertoire of emotional tunes differs from culture to culture" (p. 10). For emotion-sensitive interactive robots to function effectively within different cultures, it is important to acknowledge the full spectrum of the differences in the 
cultural repertoires of emotional tunes. These differences range from the strengths of the emotion features that we have seen differ between Polish and British English in the present paper, through major differences in the actual presence or absence of features that are exhibited, for example, in the expression of anger in New Guinea and the USA, to instances in which there is the lack of an emotion that exists in another culture, as can be seen in the lack of corresponding emotions to English grief in German, French, Polish or Russian [34].

A final, fundamental lesson to be gained from the results concerns the different manifestations of the same emotion or types of the same emotion. As Barrett [3] states, the expression of anger, for example, can take many forms depending on the circumstances, including a driver shouting and shaking their fist, an employee sitting quietly in a boardroom while listening to unfair criticism from the boss, or a teacher speaking sternly but cordially to a pupil because of their misdemeanour. This might explain the apparent paradox in our results that show that fear is relatively more likely to have a loud, assertive voice, but to also have a quieter voice than strach. Whereas the louder, more assertive version of fear is consistent with the manifestation of fight scenarios, the presence of a quieter voice in fear is typical of fright ones. It is clear that context is a major influence on differences in the outward expression of instances of the same emotion. If socially interactive robots are to accurately decode different manifestations of the same emotion, further work is necessary to develop the modelling needed to integrate expressive, sensory cues and contextual cues. The likely culture-dependent nature of this interplay between expressive and sensory cues presents further challenges to our aspirations regarding the competence of robots in the social sphere.

\section{Conclusions}

The different profiles that we observed for joy, sadness, fear and anger in both Polish and British English show that the behavioural expression and body activity GRID features that were selected can reliably distinguish between the outward expression of different emotions, while the corpusbased analysis provides important data on the circumstantial characteristics typical of particular culture-specific Emotion Events scenarios. Weightings of these features can be used in robotic modelling to create robots that can competently respond to human emotions in social settings.

The cognitive corpus linguistics approach provides information on the probabilities of the occurrence of some linguistic patterns of emotional language use based on their frequencies and distributional criteria. It has enriched the GRID analysis by identifying details of the bodily reaction (e.g. Pol. $i$ czuła strach, $i$ czuła niemoc 'and she was feeling fear, and she was feeling weakness') and provides more thorough information on causes and Experiencers of particular emotions (e.g. Pol. Ciotka, bezsilna, umierata ze strachu $i$ modlita sie 'Aunt, helpless, was dying of fear and praying'). This methodology more closely determines the contextual conditioning of particular emotions and corresponding behavioural correlates.

By enriching and more deeply specifying the description, the method provides sufficient data to model culture-bound emotional behaviour by resorting to the clusters of preferential conditions present in the implementation of a particular Emotions Event scenario in a given cultural and linguistic context. Thus, the combined GRID and corpus methodologies identify more detailed patterns and cross-linguistic and cross-cultural consistency in emotions.

The different profiles that we observe for the emotions described in the present study in both Polish and British English show that the cognitive corpus method successfully extends the identification of emotion display in different cultures for affective robotics purposes.

From our cross-cultural comparison of Polish versus British English, it would appear that if emotion-sensitive interactive robots are to be employed in different cultures, they need to be tuned to the unique profiles of emotion features that are present in these cultures.

Open Access This article is distributed under the terms of the Creative Commons Attribution License which permits any use, distribution, and reproduction in any medium, provided the original author(s) and the source are credited.

\section{Appendix 1: Corpus-Based English and Polish Collocations}

\section{HASK Collocation Database}

A RAW FREQUENCIES of COLLOCATES, i.e. words typically co-occurring with other ones with a frequency greater than chance.

TTEST $-t$ test (probability of statistical significance).

MI-Mutual Information of two random variables is a measure of the variables' mutual dependence.

Note:

1. All the lexical forms in the tables below are given in their basic lemma forms. 
2. Polish emotion collocates (e.g. wywotać 'call forth' (single act), wywotywać 'call forth (frequentative)) are not marked for such aspectual linguistic form, as it is not of immediate relevance for the present study.

Collocation tables (displayed are collocates of top (1-15) frequencies of occurrence in relevant collocational combinations):

\section{(1) ENGLISH SADNESS}

SADNESS Adjectives

\begin{tabular}{lllrcc}
\hline$\#$ & Collocate & POS & \multicolumn{1}{l}{$A$} & \multicolumn{1}{l}{ TTEST } & \multicolumn{1}{l}{ MI } \\
\hline 1 & great & AJ \% & 41.0 & 5.33843 & 2.58833721656818 \\
2 & deep & AJ \% & 16.0 & 3.70009 & 3.73738426346774 \\
3 & post-coital & AJ \% & 3.0 & 1.73068 & 10.3049601319919 \\
4 & unutterable & AJ \% & 3.0 & 1.7305 & 10.12438788635 \\
5 & sweet & AJ \% & 3.0 & 1.44206 & 2.57840135288688 \\
6 & considerable & AJ \% & 3.0 & 0.86792 & 1.00315912081529 \\
7 & certain & AJ \% & 5.0 & 0.71226 & 0.553282186304275 \\
8 & real & AJ \% & 4.0 & 0.24479 & 0.188356249117633 \\
9 & only & AJ \% & 4.0 & 0.22874 & 0.17522634327603 \\
10 & personal & AJ \% & 3.0 & 0.14983 & 0.1305337383146 \\
11 & old & AJ \% & 3.0 & -3.03943 & -1.46195521031649 \\
\hline
\end{tabular}

SADNESS Nouns

No results for Nouns

SADNESS Verbs

\begin{tabular}{llrrrl}
\hline$\#$ & Collocate & POS & \multicolumn{1}{l}{$A$} & \multicolumn{1}{l}{ TTEST } & \multicolumn{1}{l}{ MI } \\
\hline 1 & feel & V \% & 20.0 & 3.67358 & 2.48549111345927 \\
2 & tinge & V \% & 11.0 & 3.31293 & 9.81007172803188 \\
3 & express & V \% & 11.0 & 3.09355 & 3.8941018385125 \\
4 & anger & V \% & 6.0 & 2.42786 & 6.8234922437942 \\
5 & bring & V \% & 5.0 & 1.06246 & 0.930012083137449 \\
6 & leave & V \% & 6.0 & 0.92139 & 0.680741003706379 \\
7 & show & V \% & 5.0 & 0.61357 & 0.462745645764912 \\
8 & come & V \% & 9.0 & 0.01509 & 0.00727615734478037 \\
9 & see & V \% & 6.0 & -2.22615 & -0.932682136020077 \\
10 & have & V \% & 22.0 & -12.10608 & -1.84037264045196 \\
11 & be & V \% & 85.0 & -18.36053 & -1.58085903608248 \\
\hline
\end{tabular}

\section{(2) ENGLISH JOY}

\begin{tabular}{llllll}
\multicolumn{2}{l}{ JOY } & Adjs \\
\hline$\#$ & Collocate & POS & $A$ & TTEST & MI \\
\hline 1 & great & AJ \% & 91.0 & 8.21199 & 1.45116082559955 \\
2 & sheer & AJ \% & 31.0 & 5.46154 & 4.48146935420587 \\
3 & full & AJ \% & 35.0 & 4.55693 & 3.15726586910922 \\
\hline
\end{tabular}

\begin{tabular}{lllrll}
\hline$\#$ & Collocate & POS & $A$ & TTEST & MI \\
\hline 4 & pure & AJ \% & 20.0 & 4.25519 & 2.10490928709158 \\
5 & parliamentary & AJ \% & 18.0 & 3.94945 & 2.08215907439554 \\
6 & christian & AJ \% & 17.0 & 3.68695 & 5.81797661356042 \\
7 & greatest & AJ \% & 14.0 & 3.3454 & 1.34100585447265 \\
8 & holy & AJ \% & 11.0 & 3.05711 & 2.54405389158389 \\
9 & surprise & AJ \% & 10.0 & 2.86995 & 4.76644631292034 \\
10 & real & AJ \% & 18.0 & 2.7058 & 4.24178432246699 \\
11 & inner & AJ \% & 9.0 & 2.57068 & 3.77915736466989 \\
12 & overwhelming & AJ \% & 7.0 & 2.49813 & 2.908174422532 \\
13 & sudden & AJ \% & 8.0 & 2.4421 & 1.59839737811546 \\
14 & delirious & AJ \% & 6.0 & 2.4363 & 1.2034452214265 \\
\hline
\end{tabular}

JOY Nouns

No results for Nouns.

JoY Verbs

\begin{tabular}{lllrll}
\hline$\#$ & Collocate & POS & \multicolumn{1}{l}{$A$} & TTEST & MI \\
\hline 1 & bring & V \% & 45.0 & 5.11322 & 2.07238518478562 \\
2 & jump & V \% & 22.0 & 4.42203 & 4.12734149430893 \\
3 & experience & V \% & 17.0 & 3.72569 & 3.3750160016443 \\
4 & discover & V \% & 17.0 & 3.49437 & 2.71319731258343 \\
5 & watch & V \% & 19.0 & 3.28279 & 2.01813319331679 \\
6 & dance & V \% & 12.0 & 3.22497 & 3.85660829582823 \\
7 & share & V \% & 15.0 & 3.18227 & 2.4872866000158 \\
8 & express & V \% & 15.0 & 3.09412 & 2.31400891568958 \\
9 & ride & V \% & 11.0 & 2.93783 & 3.1302361482513 \\
10 & weep & V \% & 8.0 & 2.72744 & 4.80778658684817 \\
11 & behold & V \% & 7.0 & 2.622 & 6.79979781966958 \\
12 & burst & V \% & 7.0 & 2.42307 & 3.57059291714063 \\
13 & fill & V \% & 10.0 & 2.33468 & 1.93396643371412 \\
14 & leap & V \% & 6.0 & 2.24295 & 3.56802080905893 \\
15 & sing & V \% & 7.0 & 2.11207 & 2.3096195045729 \\
\hline
\end{tabular}

\section{(3) ENGLISH FEAR}

\begin{tabular}{lllrll}
\multicolumn{2}{l}{ FEAR } & Adjs \\
\cline { 3 - 6 }$\#$ & Collocate & POS & \multicolumn{1}{l}{$A$} & TTEST & MI \\
\hline 1 & worst & AJ \% & 86.0 & 8.38425 & 3.38228100815277 \\
2 & greatest & AJ \% & 34.0 & 4.21557 & 1.85185415160397 \\
3 & well-founded & AJ \% & 15.0 & 3.83541 & 6.68766164915101 \\
4 & irrational & AJ \% & 15.0 & 3.63503 & 4.02469663642858 \\
5 & widespread & AJ \% & 22.0 & 3.4081 & 1.87096886251407 \\
6 & morbid & AJ \% & 10.0 & 3.05668 & 4.90428559002784 \\
7 & respectable & AJ \% & 13.0 & 2.99449 & 2.56081974114867 \\
8 & deep-seated & AJ \% & 9.0 & 2.90921 & 5.04627371496703 \\
9 & grow & AJ \% & 25.0 & 2.85348 & 1.21993070729522 \\
10 & real & AJ \% & 63.0 & 2.71845 & 0.60492121814307 \\
11 & genuine & AJ \% & 17.0 & 2.64852 & 1.48342247691651 \\
\hline & & & & &
\end{tabular}




\begin{tabular}{lllrll}
\hline$\#$ & Collocate & POS & \multicolumn{1}{c}{ A } & TTEST & MI \\
\hline 12 & illogical & AJ \% & 7.0 & 2.48922 & 4.07911232811223 \\
13 & sudden & AJ \% & 17.0 & 2.43948 & 1.2921614385293 \\
14 & superstitious & AJ \% & 6.0 & 2.32459 & 4.29358376850781 \\
\hline
\end{tabular}

FEAR Nouns

\begin{tabular}{llrrll}
\hline$\#$ & Collocate & POS & \multicolumn{1}{l}{$A$} & TTEST & MI \\
\hline 1 & anxiety & $\mathrm{N} \%$ & 22.0 & 4.41778 & 4.10464990159163 \\
2 & reason & $\mathrm{N} \%$ & 39.0 & 4.37086 & 1.73647388439119 \\
3 & police & $\mathrm{N} \%$ & 37.0 & 4.20271 & 1.69395520411614 \\
4 & expert & $\mathrm{N} \%$ & 19.0 & 3.68369 & 2.69055847619429 \\
5 & official & $\mathrm{N} \%$ & 19.0 & 3.58185 & 2.48788455526085 \\
6 & violence & $\mathrm{N} \%$ & 17.0 & 3.56933 & 2.8963478928712 \\
7 & loss & $\mathrm{N} \%$ & 23.0 & 3.47778 & 1.86337567525088 \\
8 & environmentalist & $\mathrm{N} \%$ & 12.0 & 3.38719 & 5.4931218444191 \\
9 & critic & $\mathrm{N} \%$ & 14.0 & 3.32956 & 3.18263204014131 \\
10 & death & $\mathrm{N} \%$ & 24.0 & 3.01652 & 1.37986500396937 \\
11 & anger & $\mathrm{N} \%$ & 11.0 & 2.92232 & 3.07234252054536 \\
12 & consequence & $\mathrm{N} \%$ & 13.0 & 2.7172 & 2.02102534766134 \\
13 & observer & $\mathrm{N} \%$ & 9.0 & 2.57939 & 2.83440769591726 \\
14 & pain & $\mathrm{N} \%$ & 12.0 & 2.50461 & 1.85213597648825 \\
15 & doctor & $\mathrm{N} \%$ & 16.0 & 2.49418 & 1.4094525763272 \\
\hline
\end{tabular}

FEAR Verbs

\begin{tabular}{|c|c|c|c|c|c|}
\hline$\#$ & Collocate & POS & $A$ & TTEST & MI \\
\hline 1 & express & $\mathrm{V} \%$ & 128.0 & 10.54204 & 3.87395526540072 \\
\hline 2 & allay & $\mathrm{V} \%$ & 61.0 & 7.78987 & 8.58183478778567 \\
\hline 3 & overcome & $\mathrm{V} \%$ & 49.0 & 6.65938 & 4.36112434268113 \\
\hline 4 & confirm & $\mathrm{V} \%$ & 45.0 & 5.78048 & 2.85415853515117 \\
\hline 5 & raise & V \% & 55.0 & 5.5502 & 1.99073126057856 \\
\hline 6 & live & $\mathrm{V} \%$ & 68.0 & 5.53562 & 1.60512345790394 \\
\hline 7 & tremble & $\mathrm{V} \%$ & 27.0 & 4.99968 & 4.72502063178775 \\
\hline 8 & grow & $\mathrm{V} \%$ & 42.0 & 4.42946 & 1.65963132681028 \\
\hline 9 & lose & $\mathrm{V} \%$ & 51.0 & 4.40847 & 1.38575080750967 \\
\hline 10 & dismiss & $\mathrm{V} \%$ & 25.0 & 4.38351 & 3.01976885081675 \\
\hline 11 & dispel & $\mathrm{V} \%$ & 16.0 & 3.91894 & 5.62486590864961 \\
\hline 12 & ease & $\mathrm{V} \%$ & 17.0 & 3.70883 & 3.31506846989762 \\
\hline 13 & paralyse & $\mathrm{V} \%$ & 14.0 & 3.66417 & 5.59364149991436 \\
\hline 14 & grip & $\mathrm{V} \%$ & 14.0 & 3.51272 & 4.03064939902881 \\
\hline 15 & conquer & V \% & 12.0 & 3.33719 & 4.77062459896117 \\
\hline
\end{tabular}

\section{(4) ENGLISH ANGER}

ANGER Adj

\begin{tabular}{llllll}
\hline$\#$ & Collocate & POS & $A$ & MI & TTEST \\
\hline 1 & suppress & AJ \% & 12.0 & 4.85282571872024 & 3.43412 \\
2 & sudden & AJ \% & 16.0 & 7.98637993928282 & 3.3923 \\
3 & righteous & AJ \% & 10.0 & 7.82352946360078 & 3.12551 \\
\hline
\end{tabular}

\begin{tabular}{lllrll}
\hline$\#$ & Collocate & POS & \multicolumn{1}{l}{$A$} & MI & TTEST \\
\hline 4 & pent-up & AJ \% & 7.0 & 3.1310922345703 & 2.62304 \\
5 & frustrated & AJ \% & 7.0 & 2.5126359051346 & 2.53489 \\
6 & grow & AJ \% & 12.0 & 8.190738437789 & 2.37919 \\
7 & widespread & AJ \% & 8.0 & 7.48548170335014 & 2.0838 \\
8 & genuine & AJ \% & 8.0 & 5.90372875910487 & 2.07571 \\
9 & bitter & AJ \% & 7.0 & 3.68393979006403 & 2.06477 \\
10 & savage & AJ \% & 5.0 & 2.58947412473875 & 2.05493 \\
11 & simmer & AJ \% & 4.0 & 5.46874768759034 & 1.951 \\
12 & impotent & AJ \% & 4.0 & 3.22958936676036 & 1.92945 \\
13 & fierce & AJ \% & 5.0 & 4.12839894415525 & 1.78703 \\
14 & passionate & AJ \% & 4.0 & 2.04408675710745 & 1.70603 \\
15 & sullen & AJ \% & 3.0 & 3.04408675710745 & 1.64681 \\
\hline
\end{tabular}

ANGER Nouns

\begin{tabular}{llrrll}
\hline$\#$ & Collocate & POS & $A$ & TTEST & MI \\
\hline 1 & frustration & $\mathrm{N} \%$ & 28.0 & 5.27069 & 7.99038955253895 \\
2 & pain & $\mathrm{N} \%$ & 10.0 & 2.98635 & 4.16787102949495 \\
3 & fear & $\mathrm{N} \%$ & 10.0 & 2.9646 & 3.99974288348593 \\
4 & grief & $\mathrm{N} \%$ & 7.0 & 2.6095 & 6.18953034177411 \\
5 & sadness & $\mathrm{N} \%$ & 6.0 & 2.42786 & 6.8234922437942 \\
6 & guilt & $\mathrm{N} \%$ & 6.0 & 2.40267 & 5.70932122387489 \\
7 & love & $\mathrm{N} \%$ & 7.0 & 2.2727 & 2.82622261057866 \\
8 & environmentalist & $\mathrm{N} \%$ & 5.0 & 2.21612 & 6.8088568974258 \\
9 & resentment & $\mathrm{N} \%$ & 5.0 & 2.20327 & 6.09128690154808 \\
10 & despair & $\mathrm{N} \%$ & 5.0 & 2.19705 & 5.84056575715314 \\
11 & anxiety & $\mathrm{N} \%$ & 5.0 & 2.14034 & 4.5459158366822 \\
12 & desire & $\mathrm{N} \%$ & 5.0 & 2.06153 & 3.67931787923079 \\
13 & plan & $\mathrm{N} \%$ & 5.0 & 1.54821 & 1.70078704756518 \\
14 & decision & $\mathrm{N} \%$ & 5.0 & 1.4886 & 1.58087479439372 \\
15 & Mr & $\mathrm{N} \%$ & 5.0 & 0.64515 & 0.491107238190879 \\
\hline
\end{tabular}

ANGER Verbs

\begin{tabular}{llllll}
\hline$\#$ & Collocate & POS & $A$ & TTEST & MI \\
\hline 1 & express & V \% & 66.0 & 7.74773 & 4.43221495690917 \\
2 & feel & V \% & 64.0 & 6.15543 & 2.11671363624743 \\
3 & vent & V \% & 25.0 & 4.99151 & 9.20196410557751 \\
4 & rise & V \% & 24.0 & 4.13709 & 2.68482441228638 \\
5 & provoke & V \% & 17.0 & 3.99844 & 5.04763040233376 \\
6 & control & V \% & 20.0 & 3.85721 & 2.8624896857616 \\
7 & direct & V \% & 17.0 & 3.79197 & 3.63825635473554 \\
8 & tremble & V \% & 15.0 & 3.78068 & 5.39088929738279 \\
9 & suppress & V \% & 13.0 & 3.50909 & 5.2241961291531 \\
10 & seethe & V \% & 12.0 & 3.45044 & 7.98672838735455 \\
11 & flush & V \% & 12.0 & 3.39574 & 5.66324146461063 \\
12 & boil & V \% & 12.0 & 3.37795 & 5.32952100216352 \\
13 & arouse & V \% & 12.0 & 3.36474 & 5.12364715326055 \\
14 & turn & V \% & 29.0 & 3.30523 & 1.37245215503444 \\
15 & explode & V \% & 11.0 & 3.19218 & 4.73615410250922 \\
\hline
\end{tabular}




\section{(5) POLISH SMUTEK 'sadness'}

SMUTEK 'sadness' Adjs

\begin{tabular}{lllrlll}
\hline$\#$ & Collocate & POS & \multicolumn{1}{l}{ A } & TTEST & MI & $\begin{array}{l}\text { English } \\
\text { equivalents }\end{array}$ \\
\hline 1 & & & & & & deep \\
2 & głęboki & adj & 100.0 & 9.62014 & 4.718384525917518 & full \\
3 & pełny & adj & 74.0 & 7.08764 & 2.505712563981208 & great \\
4 & wielki & adj & 140.0 & 6.70255 & 1.2057934153992946 & piercing \\
5 & przejmujący & adj & 21.0 & 4.49927 & 5.781630909286284 & boundless \\
6 & bezbrzeżny & adj & 20.0 & 4.46241 & 8.844940564569718 & huge \\
7 & ogromny & adj & 28.0 & 3.75628 & 1.7852289021035994 & some \\
8 & jakiś & adj & 68.0 & 3.75626 & 0.8770307726918485 & sudden \\
9 & nagły & adj & 15.0 & 3.43592 & 3.1475205342043675 & hopeless \\
10 & beznadziejny & adj & 11.0 & 3.16989 & 4.498455365438376 & strange \\
11 & dziwny & adj & 18.0 & 3.16796 & 3.9810526740358376 & indefinite \\
12 & nieokreślony & adj & 11.0 & 3.1565 & 4.3724172957799885 & terrible \\
13 & straszny & adj & 14.0 & 3.08689 & 2.5146336578758195 & your \\
14 & twój & adj & 28.0 & 3.07065 & 1.2525660262079732 & sincere \\
15 & szczery & adj & 11.0 & 2.96564 & 3.2402250202761476 & total, boundless \\
\hline
\end{tabular}

SMUTEK 'sadness' Nouns

\begin{tabular}{lllllll}
\hline$\#$ & Collocate & POS & $A$ & TTEST & MI & $\begin{array}{l}\text { English } \\
\text { equivalents }\end{array}$ \\
\hline 1 & tropik & Noun & 25.0 & 4.97285 & 7.524649762807013 & tropic \\
2 & emancypantka & Noun & 10.0 & 3.14985 & 7.991593411377508 & emancipation \\
3 & rozstanie & Noun & 9.0 & 2.66026 & 3.1424507042594403 & parting, departure \\
4 & trening & Noun & 9.0 & 1.32917 & 0.8443968839372704 & training \\
5 & głowa & Noun & 24.0 & -3.91244 & -0.846892874062491 & head \\
6 & życie & Noun & 11.0 & -28.51125 & -3.262502915343643 & life \\
7 & pan & Noun & 14.0 & -64.37188 & -4.186192169945479 & lord, sir \\
\hline
\end{tabular}

SMUTEK 'sadness' Verbs

\begin{tabular}{lllllll}
\hline$\#$ & Collocate & POS & A & TTEST & MI & English equivalents \\
\hline 1 & pogrążyć & Verb & 104.0 & 10.15996 & 8.06501751021011 & plunge \\
2 & powiedzieć & Verb & 104.0 & 6.82096 & 1.5944442024143786 & say, perf. \\
3 & ogarną́c & Verb & 44.0 & 6.53829 & 6.126319255129692 & overwhelm, perf. \\
4 & czuć & Verb & 59.0 & 6.49102 & 2.6902026984347276 & feel \\
5 & stwierdzić & Verb & 49.0 & 6.1137 & 2.9814933148417393 & state, perf. \\
6 & ogarniać & Verb & 36.0 & 5.93357 & 6.4970509794751035 & overwhelm \\
7 & stwierdzać & Verb & 38.0 & 5.6447 & 3.568165293643454 & state, perf. \\
8 & mówić & Verb & 117.0 & 5.60903 & 1.054556337395112 & speak \\
9 & patrzyć & Verb & 44.0 & 5.47989 & 2.5238720909196486 & look \\
10 & napawać & Verb & 30.0 & 5.44322 & 7.331627370267731 & fill with \\
11 & odczuwać & Verb & 30.0 & 5.23914 & 4.5238736014930625 & feel \\
12 & pokiwać & Verb & 26.0 & 5.05222 & 6.76757908543353 & nod \\
13 & topić & Verb & 24.0 & 4.86758 & 7.285823680654605 & sink \\
14 & pomyśleć & Verb & 31.0 & 4.86632 & 2.9887003218132326 & think, perf. \\
15 & poczuć & Verb & 28.0 & 4.81192 & 3.4638219826326004 & feel, perf. \\
\hline
\end{tabular}




\section{(6) POLISH RADOŚĆ 'joy'}

RADOŚć ‘joy’ Adjs

\begin{tabular}{lllllll}
\hline$\#$ & Collocate & POS & A & TTEST & MI & English equivalents \\
\hline 1 & wielki & Adj & 1211.0 & 29.06444 & 2.6012025050944603 & great \\
2 & ogromny & Adj & 364.0 & 17.67869 & 3.768377577190495 & huge \\
3 & pełny & Adj & 245.0 & 12.91525 & 2.5156060943006318 & full \\
4 & wieczny & Adj & 136.0 & 11.19583 & 4.645093820893503 & eternal \\
5 & prawdziwy & Adj & 158.0 & 9.9288 & 2.2508007593498993 & true \\
6 & mój & Adj & 321.0 & 7.19571 & 0.7408796619335235 & my \\
7 & szczery & Adj & 49.0 & 6.45318 & 3.678212202699862 & sincere \\
8 & nieopisany & Adj & 32.0 & 5.60824 & 6.862552649224834 & undescribable \\
9 & spontaniczny & Adj & 33.0 & 5.50789 & 4.601210707198511 & spontaneous \\
10 & jaki & Adj & 263.0 & 5.44058 & 0.5896169130698841 & what \\
11 & wspólny & Adj & 81.0 & 5.21569 & 1.2498953913064068 & common \\
12 & autentyczny & Adj & 33.0 & 5.19278 & 3.380028405333701 & authentic \\
13 & niekłamany & Adj & 26.0 & 5.05267 & 6.781632653841267 & genuine, unfeigned \\
14 & jakiż & Adj & 28.0 & 4.9899 & 4.132966585424224 & what \\
15 & dziki & Adj & 32.0 & 4.98768 & 3.079554440304421 & wild \\
\hline
\end{tabular}

RADOŚć ‘joy’ Nouns

\begin{tabular}{|c|c|c|c|c|c|c|}
\hline$\#$ & Collocate & POS & $A$ & TTEST & English equivalents & MI \\
\hline 1 & życie & Noun & 881.0 & 17.9874 & life & 1.3437726318852765 \\
\hline 2 & być & Noun & 31.0 & 4.40434 & be & 2.258720377146277 \\
\hline 3 & granie & Noun & 23.0 & 3.87483 & playing & 2.3805130933913694 \\
\hline 4 & istnieć & Noun & 47.0 & 3.56654 & exist & 1.0595934265879448 \\
\hline 5 & macierzyństwo & Noun & 16.0 & 3.33612 & maternity & 2.590995027829863 \\
\hline 6 & dawać & Noun & 11.0 & 3.07789 & give & 3.796221775610776 \\
\hline 7 & obcowanie & Noun & 12.0 & 2.8622 & commune with & 2.5248920077904597 \\
\hline 8 & zmartwychwstanie & Noun & 12.0 & 2.61664 & resurrection & 2.031269818607729 \\
\hline 9 & przebywać & Noun & 11.0 & 2.42724 & be & 1.898840577173269 \\
\hline 10 & odkrywać & Noun & 9.0 & 2.39666 & uncover & 2.313924419910811 \\
\hline 11 & leń & Noun & 7.0 & 2.30152 & lazyboned & 2.94220724727895 \\
\hline 12 & tworzyć & Noun & 40.0 & 1.84586 & create & 0.497885623438381 \\
\hline 13 & niebo & Noun & 44.0 & 1.62614 & heaven & 0.4057367698498833 \\
\hline 14 & $\operatorname{sex}$ & Noun & 12.0 & 1.39106 & $\operatorname{sex}$ & 0.7407349083963752 \\
\hline 15 & kibic & Noun & 30.0 & 1.1957 & sports fan & $\begin{array}{l}0.3553210853880615 \\
0.45362758262754654\end{array}$ \\
\hline
\end{tabular}

RADOŚĆ ‘joy’ Verbs

\begin{tabular}{lllllll}
\hline$\#$ & Collocate & POS & $A$ & TTEST & MI & English equivalents \\
\hline 1 & sprawiać & Verb & 504.0 & 22.08733 & 5.952141330543243 & cause \\
2 & sprawić & Verb & 447.0 & 20.82657 & 6.06497899598923 & cause, perf. \\
3 & dawać & Verb & 393.0 & 18.23574 & 3.641537326575362 & give \\
4 & przyjać & Verb & 203.0 & 12.05626 & 2.7007213612338243 & receive \\
5 & czerpać & Verb & 149.0 & 11.99963 & 5.882389373724917 & draw, take \\
\hline
\end{tabular}




\begin{tabular}{lllllll}
\hline$\#$ & Collocate & POS & $A$ & TTEST & MI & English equivalents \\
\hline 6 & przynosić & Verb & 153.0 & 11.81848 & 4.4889955661110506 & bring \\
7 & wyrażać & Verb & 134.0 & 10.97441 & 4.266579242474314 & express \\
8 & kryć & Verb & 118.0 & 10.40984 & 4.583935563803693 & hide \\
9 & wyrazić & Verb & 123.0 & 10.322 & 3.8510735420144098 & express, perf. \\
10 & przeżywać & Verb & 113.0 & 10.188 & 4.5874882621293835 & live through \\
11 & zapanować & Verb & 106.0 & 10.1409 & 6.056138762829899 & control \\
12 & ukrywać & Verb & 111.0 & 9.9533 & 4.177236789131274 & hide \\
13 & dzielić & Verb & 113.0 & 9.93135 & 3.927155415672382 & share \\
14 & odczuwać & Verb & 105.0 & 9.82848 & 4.613937480496469 & feel \\
15 & witać & Verb & 101.0 & 9.52409 & 4.256566312537501 & greet \\
\hline
\end{tabular}

\section{(7) POLISH STRACH 'fear'}

STRACH 'fear' Adjs

\begin{tabular}{lllllll}
\hline$\#$ & Collocate & POS & A & TTEST & MI & English equivalents \\
\hline 1 & blady & Adj & 175.0 & 13.0097 & 5.916250334092935 & pale \\
2 & paniczny & Adj & 156.0 & 12.46428 & 8.92411439987302 & panic \\
3 & ciągły & Adj & 112.0 & 10.08541 & 4.410619730980793 & continuous \\
4 & paraliżujący & Adj & 63.0 & 7.90518 & 7.9512505298105305 & paralysing \\
5 & wielki & Adj & 289.0 & 6.72895 & 0.7269513218272461 & great \\
6 & zwierzęcy & Adj & 38.0 & 5.8744 & 4.409768213512196 & animal \\
7 & zwykły & Adj & 58.0 & 5.85945 & 2.116431208572637 & usual \\
8 & irracjonalny & Adj & 29.0 & 5.27866 & 5.659998918648893 & irrational \\
9 & nagły & Adj & 36.0 & 5.18837 & 2.8860701809104006 & sudden \\
10 & silny & Adj & 58.0 & 4.9082 & 1.49198887479362 & strong \\
11 & oszalały & Adj & 24.0 & 4.83715 & 6.308125003531237 & mad \\
12 & zabobonny & Adj & 23.0 & 4.7656 & 7.309460214215058 & superstitious \\
13 & polny & Adj & 25.0 & 4.68595 & 3.992842449031162 & field \\
14 & własny & Adj & 124.0 & 4.61105 & 0.7712358127333814 & own \\
15 & ludzki & Adj & 58.0 & 4.55647 & 1.315786141623697 & human \\
16 & wieczny & Adj & 26.0 & 4.16641 & 2.4508769817106897 & eternal \\
\hline
\end{tabular}

STRACH 'fear' Nouns

\begin{tabular}{lllrlll}
\hline$\#$ & Collocate & POS & \multicolumn{1}{c}{ A } & TTEST & English equivalents & MI \\
\hline 1 & gardło & Noun & 7.0 & -0.89811 & throat & -0.42164320669473987 \\
2 & zwierze & Noun & 8.0 & -11.04438 & animal & -2.2941874842625167 \\
3 & serce & Noun & 7.0 & -17.56287 & heart & -2.933221290580398 \\
4 & oko & Noun & 25.0 & -21.57289 & eye & -2.4099552416192616 \\
5 & twarz & Noun & 7.0 & -22.2505 & face & -3.234179425924676 \\
6 & śmierć & Noun & 7.0 & -27.53372 & death & -3.5118181858857818 \\
7 & mieszkaniec & Noun & 11.0 & -30.41866 & inhabitant & -3.3464705273192554 \\
8 & człowiek & Noun & 17.0 & -36.95889 & human being & -3.316702864486338 \\
9 & kobieta & Noun & 7.0 & -51.02267 & woman & -4.342324076374389 \\
10 & ludzie & Noun & 22.0 & -57.01557 & people & -3.717622771413607 \\
11 & dziecko & Noun & 18.0 & -58.50026 & child & -3.8864179165228476 \\
12 & nic & Noun & 8.0 & -66.75124 & nothing & -4.620593769285852 \\
13 & co & Noun & 9.0 & -351.53801 & what & -6.884833981019253 \\
\hline
\end{tabular}


STRACH 'fear' Verbs

\begin{tabular}{|c|c|c|c|c|c|c|}
\hline$\#$ & Collocate & POS & A & TTEST & MI & English equivalents \\
\hline 1 & pomyśleć & Verb & 493.0 & 21.69759 & 5.455463088676508 & think \\
\hline 2 & czuć & Verb & 258.0 & 14.42509 & 3.2943021453683787 & feel \\
\hline 3 & budzić & Verb & 225.0 & 14.39148 & 4.623507549794386 & wake \\
\hline 4 & żyć & Verb & 204.0 & 12.60056 & 3.0857761781248367 & live \\
\hline 5 & paść & Verb & 166.0 & 12.37227 & 4.653797252825121 & fall \\
\hline 6 & trząść & Verb & 136.0 & 11.55448 & 6.7624001168971555 & shiver \\
\hline 7 & odczuwać & Verb & 135.0 & 11.29606 & 5.169313843807614 & feel \\
\hline 8 & drżeć & Verb & 120.0 & 10.82621 & 6.4165104245294025 & tremble \\
\hline 9 & ogarniać & Verb & 111.0 & 10.42682 & 6.597057085255134 & overwhelm \\
\hline 10 & umierać & Verb & 111.0 & 10.23981 & 5.1542885757663095 & die \\
\hline 11 & poczuć & Verb & 118.0 & 10.1907 & 4.0146253508090775 & feel \\
\hline 12 & sparaliżować & Verb & 98.0 & 9.83392 & 7.238033012154485 & paralyse, perf. \\
\hline 13 & napędzić & Verb & 94.0 & 9.68509 & 9.882968365928376 & drive, increase \\
\hline 14 & ogarnąć & Verb & 96.0 & 9.61302 & 5.72736537808579 & overwhelm \\
\hline 15 & paraliżować & Verb & 85.0 & 9.18782 & $\begin{array}{l}8.183181598710803 \\
5.4369804240091195\end{array}$ & paralyse \\
\hline
\end{tabular}

\section{(8) POLISH GNIEW 'anger 1'}

GNIEW 'anger 1' Adjs

\begin{tabular}{lllllll}
\hline$\#$ & Collocate & POS & A & TTEST & English equivalents & MI \\
\hline 1 & słuszny & Adj & 59.0 & 7.46235 & right, rational, justified & 5.133641347994825 \\
2 & swój & Adj & 186.0 & 6.22434 & one's & 0.8793581420934464 \\
3 & boży & Adj & 39.0 & 5.81522 & godly & 3.8610308496554664 \\
4 & bezsilny & Adj & 32.0 & 5.60193 & powerless & 6.686423975874181 \\
5 & nagły & Adj & 34.0 & 5.56835 & sudden & 4.4728081923281096 \\
6 & straszny & Adj & 30.0 & 5.07263 & terrible & 3.7588847439086552 \\
7 & twój & Adj & 37.0 & 4.3352 & your & 1.7993798822612401 \\
8 & srogi & Adj & 18.0 & 4.18748 & severe & 6.2651274861236566 \\
9 & pełny & Adj & 37.0 & 4.14513 & full & 1.650427976463129 \\
10 & klasowy & Adj & 17.0 & 4.03112 & class & 5.486234655668294 \\
11 & niepohamowany & Adj & 15.0 & 3.84909 & irrepressible, uncontrollable & 7.340772539466548 \\
12 & czerwony & Adj & 19.0 & 3.58688 & red & 2.4972598404622723 \\
13 & straszliwy & Adj & 14.0 & 3.5717 & terrible & 4.4604516642619325 \\
14 & pański & Adj & 15.0 & 3.40364 & lordly & 3.0447439233724785 \\
15 & boski & Adj & 15.0 & 3.39431 & godly & 3.0163455875091376 \\
\hline
\end{tabular}

GNIEW 'anger 1' Nouns

\begin{tabular}{llllccl}
\hline$\#$ & Collocate & POS & A & TTEST & MI & English equivalents \\
\hline 1 & lud & Noun & 47.0 & 6.30151 & 3.628971801934647 & people \\
2 & internauta & Noun & 29.0 & 4.75976 & 3.106119253520865 & Internaut \\
3 & Bóg & Noun & 47.0 & 2.84445 & 0.7732597322778273 & God \\
4 & niebiosy & Noun & 7.0 & 2.53815 & 4.619951241351488 & heavens \\
5 & sprawiedliwy & Noun & 8.0 & 2.44039 & 2.865724374349709 & just, fair \\
6 & ocean & Noun & 8.0 & 2.16681 & 2.095924149866194 & ocean \\
7 & przeciwnik & Noun & 7.0 & 0.12883 & 0.07201768826979889 & opponent, enemy \\
\hline
\end{tabular}




\begin{tabular}{lllrlll}
\hline$\#$ & Collocate & POS & \multicolumn{1}{c}{ A } & TTEST & MI & English equivalents \\
\hline 8 & Król & Noun & 9.0 & -0.3155 & -0.1442629042229037 & king \\
9 & twarz & Noun & 17.0 & -0.90008 & -0.28487133512225854 & face \\
10 & ojciec & Noun & 20.0 & -2.95814 & -0.7324526211322907 & father \\
11 & rodzice & Noun & 7.0 & -5.01979 & -1.5347104288155138 & parents \\
12 & głos & Noun & 8.0 & -12.78908 & -2.4650919458017606 & voice \\
13 & ludzie & Noun & 11.0 & -24.12204 & -3.048422599803925 & people \\
14 & Pan & Noun & 23.0 & -43.2737 & -3.325269723464149 & sir, lord \\
\hline
\end{tabular}

GNIEW 'anger 1' Verbs

\begin{tabular}{lllllll}
\hline$\#$ & Collocate & POS & $A$ & TTEST & MI & English equivalents \\
\hline 1 & wpadać & Verb & 72.0 & 8.38549 & 6.409836889345482 & fall into \\
2 & wywołać & Verb & 48.0 & 6.65765 & 4.67849302335714 & call forth \\
3 & wybuchać & Verb & 41.0 & 6.35229 & 6.976716404244669 & explode \\
4 & wyrażać & Verb & 39.0 & 5.93832 & 4.347898726414907 & express \\
5 & wpaść & Verb & 39.0 & 5.88082 & 4.099966903839913 & fall into, perf. \\
6 & wzbierać & Verb & 34.0 & 5.81779 & 8.791443155281893 & surge, rise \\
7 & wybuchnąć & Verb & 35.0 & 5.76411 & 5.2827672339327645 & explode, perf. \\
8 & czuć & Verb & 48.0 & 5.73467 & 2.5372375622759638 & feel \\
9 & wywoływać & Verb & 35.0 & 5.69345 & 4.731923714020757 & call forth \\
10 & bożyć & Verb & 32.0 & 5.59483 & 6.511079824024953 & God, verb \\
11 & budzić & Verb & 35.0 & 5.43095 & 3.608209547131997 & wake up \\
12 & ściągnaćc & Verb & 30.0 & 5.33645 & 5.282011667976065 & pull down \\
13 & ogarnąć & Verb & 29.0 & 5.27937 & 5.669584044101888 & embrace, overwhelm \\
14 & unosić & Verb & 27.0 & 5.06157 & 5.270891968813462 & rise \\
15 & tłumić & Verb & 26.0 & 5.06037 & & muffle, suppress \\
\hline
\end{tabular}

\section{(9) POLISH ZŁOŚĆ 'anger 2'}

Złość 'anger 2' Adjs

\begin{tabular}{lllllll}
\hline$\#$ & Collocate & POS & A & TTEST & MI & English equivalents \\
\hline 1 & bezsilny & Adj & 78.0 & 8.78705 & 7.625808557604507 & powerless \\
2 & sportowy & Adj & 68.0 & 7.26377 & 3.069284862767255 & sports \\
3 & nagły & Adj & 32.0 & 5.31281 & 4.039327713945847 & sudden \\
4 & czerwony & Adj & 36.0 & 5.28712 & 3.0732396913290763 & red \\
5 & pełny & Adj & 45.0 & 4.475 & 1.5868100700319316 & full \\
6 & swój & Adj & 181.0 & 3.90101 & 0.49402758093669774 & one's own \\
7 & wyraźny & Adj & 15.0 & 3.09777 & 2.3207817702341016 & clear \\
8 & cały & Adj & 87.0 & 3.00749 & 0.561573602491023 & all \\
9 & purpurowy & Adj & 8.0 & 2.7568 & 5.303253340324792 & purple \\
10 & zapiekły & Adj & 6.0 & 2.43906 & 7.876041127099847 & (all) consuming \\
11 & bezrozumny & Adj & 5.0 & 2.21639 & 6.82834438506855 & unreasonable, irrational, unjustified \\
12 & blady & Adj & 7.0 & 2.20803 & 2.5955766787959704 & pale \\
13 & niepohamowany & Adj & 5.0 & 2.18347 & 5.40979240161347 & uncontrollable \\
14 & pomieszany & Adj & 5.0 & 2.17521 & 5.19948545443459 & mixed \\
15 & agresywny & Adj & 7.0 & 2.13047 & 2.36025611460128 & aggressive \\
\hline
\end{tabular}


Złość 'anger 2' Nouns

\begin{tabular}{|c|c|c|c|c|c|c|}
\hline$\#$ & Collocate & POS & $A$ & TTEST & MI & English equivalents \\
\hline 1 & piękność & Noun & 10.0 & 2.87431 & 3.456980823403606 & beauty \\
\hline 2 & mama & Noun & 13.0 & -0.27559 & -0.10626141709169179 & mummy \\
\hline 3 & twarz & Noun & 11.0 & -4.62061 & -1.258920194867223 & face \\
\hline 4 & matka & Noun & 14.0 & -5.06752 & -1.235330046011042 & mother \\
\hline 5 & ojciec & Noun & 15.0 & -7.03228 & -1.493507757543057 & father \\
\hline 6 & nic & Noun & 9.0 & -23.21733 & -3.1274862333657802 & nothing \\
\hline 7 & wszystko & Noun & 15.0 & -30.76678 & -3.1609117650275143 & all \\
\hline 8 & pani & Noun & 7.0 & -32.4295 & -3.728704112702629 & lady \\
\hline 9 & dziecko & Noun & 7.0 & -37.56426 & -3.925805461429796 & child \\
\hline 10 & ludzie & Noun & 7.0 & -41.07343 & -4.046516933515541 & people \\
\hline 11 & to & Noun & 9.0 & -113.83998 & -5.283427668331679 & this \\
\hline
\end{tabular}

Złość 'anger 2' Verbs

\begin{tabular}{lllllll}
\hline$\#$ & Collocate & POS & $A$ & TTEST & MI & English equivalents \\
\hline 1 & zrobić & Verb & 154.0 & 10.93448 & 3.07248832910327 & do, perf. \\
2 & czuć & Verb & 113.0 & 9.64141 & 3.4264363868380725 & feel \\
3 & robić & Verb & 117.0 & 9.26836 & 2.8045002398402854 & do, perf. \\
4 & wpadać & Verb & 56.0 & 7.33949 & 5.7012491728288515 & fall \\
5 & rzucić & Verb & 55.0 & 6.96838 & 4.049697488096923 & throw \\
6 & poczuć & Verb & 52.0 & 6.80649 & 4.1556045540660875 & feel, perf. \\
7 & wyładować & Verb & 46.0 & 6.76473 & 8.590161504064355 & vent, perf. \\
8 & wyładowywać & Verb & 43.0 & 6.5496 & 9.708592993764878 & vent \\
9 & ogarnąć & Verb & 44.0 & 6.52408 & 5.925017030479689 & overwhelm, perf. \\
10 & pomyśleć & Verb & 42.0 & 5.78788 & 3.225519209555116 & think, perf. \\
11 & wyrażać & Verb & 38.0 & 5.76951 & 3.964406383864321 & express \\
12 & wpaść & Verb & 38.0 & 5.69547 & 3.716474561289328 & fall \\
13 & trząść & Verb & 33.0 & 5.65741 & 6.042513929483029 & shiver \\
14 & ogarniać & Verb & 31.0 & 5.48546 & 6.080020063769664 & overwhelm \\
& & & & 4.4600749005929945 & \\
\hline
\end{tabular}

\section{Appendix 2}

See Table 7.

Table 7 GRID features and their loadings on valence, power, arousal and novelty dimensions

\begin{tabular}{lc}
\hline Grid dimensions and features & Feature loadings \\
\hline Valence dimension & \\
Frowned & 0.962 \\
Pressed lips together & 0.921 \\
Withdrew from people or things & 0.882 \\
Produced a short utterance & 0.827 \\
Felt cold & 0.743 \\
Produced speech disturbances & 0.679 \\
Had a trembling voice & 0.643 \\
Produced a long utterance & -0.667 \\
Moved towards people or things & -0.837 \\
Smiled & -0.967 \\
Wanted to sing or dance & -0.975 \\
\hline
\end{tabular}


Table 7 continued

\begin{tabular}{lc}
\hline Grid dimensions and features & Feature loadings \\
\hline Power dimension & \\
Had an assertive voice & 0.908 \\
Increased the volume of voice & 0.799 \\
Spoke faster & 0.72 \\
Spoke slower & -0.682 \\
Closed his or her eyes & -0.684 \\
Decreased the volume of voice & -0.732 \\
Fell silent & -0.748 \\
Arousal dimension & \\
Breathing getting faster & 0.863 \\
Heartbeat getting faster & 0.832 \\
Sweat & 0.811 \\
Perspired/moist hands & 0.786 \\
Felt hot & 0.785 \\
Felt shivers & 0.701 \\
Abrupt bodily movements & 0.638 \\
Heartbeat slowing down & -0.658 \\
Breathing slowing down & -0.683 \\
Novelty dimension & \\
Jaw dropped & 0.82 \\
Eyebrows went up & 0.738 \\
Opened his or her eyes widely & 0.664 \\
\hline
\end{tabular}

\section{References}

1. Alonso-Arbiol I, van der Vijer FRJ. The conceptualisation of despair in Basque, Spanish, and English. In: Fontaine J, Scherer $\mathrm{KR}$, Soriano C, editors. Components of emotional meaning: a sourcebook. Oxford: Oxford University Press; 2013. p. 311-27.

2. Barber D, Reineman-Jones L, Lackey S, Hudson I. Augmenting robot behaviors using physiological measures. Lect Notes Comput Sci. 2011;6780:567-72.

3. Barrett LF. Solving the emotion paradox: categorization and the experience of emotion. Pers Soc Psychol Rev. 2006;10:20-46.

4. Castellano G, Santiago DV, Camurri A. Recognising human emotions from body movement and gesture dynamics. In: Paiva A, Prada R, Picard RW, editors. Affective computing and intelligent interaction. Berlin: Springer; 2007. p. 71-82.

5. Damasio A. Looking for spinoza: joy, sorrow, and the feeling brain. Orlando, FL: Harcourt; 2003.

6. Ekman P. Emotions revealed: recognizing faces and feelings to improve communication and emotional life. New York: Times Books; 2003.

7. Ellsworth PC, Scherer KR. Appraisal processes in emotion. In: Davidson RJ, Scherer KR, Goldsmith H, editors. Handbook of affective sciences. New York: Oxford University Press; 2003. p. 572-95.

8. Fontaine JRJ, Scherer KR, Roesch EB, Ellsworth PC. The world of emotions is not two dimensional. Psychol Sci. 2007;18:1050-7.

9. Fontaine JRJ, Scherer KR, Soriano C. Components of emotional meaning: a sourcebook. Oxford: OUP; 2013.

10. Halliday MAK. Lexis as a linguistic level. J Linguist. 1966;2(1):57-67.

11. Hofstede G. Culture's consequences: international differences in work-related values. Beverly Hills: Sage; 1980.
12. Ishii K. The meaning of happiness in Japan and the United States. In: Fontaine J, Scherer KR, Soriano C, editors. Components of emotional meaning: a sourcebook. Oxford: Oxford University Press; 2013. p. 473-6.

13. Jack RE, Garrod OGB, Yu H, Caldara R, Schyns PG. Facial expressions of emotion are not culturally universal. Proc Natl Acad Sci USA. 2012;109(19):7241-4.

14. Lakoff G. Women. Fire and dangerous things. What categories reveal about the mind. Chicago: Chicago University Press; 1987.

15. Langacker RW. Foundations of cognitive grammar, vols. 1 and 2. Stanford: Stanford University Press; 1987(1991).

16. Laukka P, Neiberg D, Elfenbein HA. Evidence for cultural dialects in vocal emotion expression: acoustic classification within and across five nations. Emotion. 2014;14(3):445-9.

17. Lewandowska-Tomaszczyk B, Wilson PA. A contrastive perspective on emotions: surprise. Rev Cogn Linguist. 2010;8(2):321-50

18. Lewandowska-Tomaszczyk B, Wilson PA. English fear and Polish strach in contrast: GRID approach and cognitive corpus linguistic methodology. In: Fontaine J, Scherer KR, Soriano C, editors. Components of emotional meaning: a sourcebook. Oxford: Oxford University Press; 2013. p. 425-36.

19. Lewandowska-Tomaszczyk B, Wilson PA. Self-conscious emotions in collectivistic and individualistic cultures: a contrastive linguistic perspective. In Romero-Trillo J, editor. Yearbook of corpus linguistics and pragmatics 2014: new empirical and theoretical paradigms. Berlin: Springer; 2014. p. 123-148.

20. Mortillaro M, Ricci-Bitti PE, Bellelli G, Galati D. Pride is not created equal: variations between Northern and Southern Italy. In: Fontaine J, Scherer KR, Soriano C, editors. Components of emotional meaning: a sourcebook. Oxford: Oxford University Press; 2013. p. 366-76. 
21. Niedenthal P, Krauth-Gruber S, Ric R. Psychology of emotion. New York: Psychology Press; 2006.

22. Ogarkova A, Fontaine JJR, Prihod'ko I. What the GRID can reveal about culture-specific emotion concepts: a case study of Russian "toska". In: Fontaine J, Scherer KR, Soriano C, editors. Components of emotional meaning: a sourcebook. Oxford: Oxford University Press; 2013. p. 425-36.

23. Ogarkova A, Soriano C, Lehr C. Naming feeling: exploring the equivalence of emotion terms in five european languages. In: Wilson PA, editor. Dynamicity in emotion concepts. Lodz studies in language, vol. 27. Frankfurt a Main: Peter Lang; 2012. p. 247-333.

24. Pęzik P. Paradygmat Dystrybucyjny w Badaniach Frazeologicznych. Powtarzalność. Reprodukcja i Idiomatyzacja. In: Stalmaszczyk. P, editor. Metodologie Jezykoznawstwa. Ewolucja Jezyka. Ewolucja Teorii Jezykoznawczych. Wydawnictwo Uniwersytetu Łódzkiego; 2013.

25. Reips UD. Standards for internet-based experimenting. Exp Psychol. 2002;49:243-56.

26. Scherer KR. What are emotions? And how can they be measured? Soc Sci Inf. 2005;44:693-727.

27. Scherer KR, Walbott HG. Evidence for universality and cultural variation of differential emotional response patterning. J Pers Soc Psychol. 1994;66:310-28.

28. Smith RW. Visual hypothesis testing with confidence intervals. In: Proceedings of the twenty-second annual SAS users group international conference (SUGI 22); 1997.

29. Tabachnick BG, Fidell LS. Using multivariate statistics. Boston: Allyn and Bacon; 2001.
30. Vogt T, André E, Wagner J. Automatic recognition of emotions from speech: a review of the literature and recommendations for practical realisation. In: Peter C, Beale R, editors. Affect and emotion in HCI, LNCS. Berlin: Springer; 2008. p. 75-91.

31. Wallbott HG. Bodily expression of emotion. Eur J Soc Psychol. 1998;28:879-96.

32. Wielki Słownik Angielsko-Polski i Polsko-Angielski 'Great English-Polish and Polish-English Dictionary'. Warszawa: Wydawnictwo Naukowe: PWN \& OUP; 2002.

33. Wierzbicka A. Emotions across languages and cultures: diversity and universals. Cambridge: Cambridge University Press; 1999.

34. Wierzbicka A. Emotion and culture: arguing with Martha Nussbaum. Ethos. 2003;31(4):577-600.

35. Wierzbicka A. Language and metalanguage: key issues in emotion research. Emot Rev. 2009;1(1):3-14.

36. Wilson PA, Lewandowska-Tomaszczyk B. The nature of emotions. In: Wilson PA, editor. Dynamicity in emotion concepts. Lodz Studies in Language, vol. 27. Frankfurt a Main: Peter Lang; 2012. p. 7-30.

37. Wilson PA, Lewandowska-Tomaszczyk B, Niiya Y. Happiness and contentment in English and Polish GRID and cognitive corpus linguistics. In: Fontaine J, Scherer KR, Soriano C, editors. Components of emotional meaning: a sourcebook. Oxford: Oxford University Press; 2013. p. 477-81.

38. Wimmer M, MacDonald BA, Jayamuni D, Yadav A. Facial expression recognition for human-robot interaction-a prototype. In: Sommer G, Reinhard K, editors. Robot vision. Berlin: Springer; 2008. p. 139-51. 